\title{
Older nurses' experiences of providing direct care in hospital nursing units: a qualitative systematic review
}

Karen Parsons $s^{1,3} \cdot$ Alice Gaudine $^{1,3} \cdot$ Michelle Swab $^{2,3}$

${ }^{1}$ School of Nursing, Memorial University of Newfoundland, St. John's, Newfoundland, Canada

${ }^{2}$ Health Sciences Library, Memorial University of Newfoundland, St. John's, Newfoundland, Canada

${ }^{3}$ Memorial University School of Nursing Collaboration for Evidence-Based Nursing and Primary Health Care: a Joanna Briggs Institute Affiliated Group

Corresponding author: Karen Parsons, karenp@mun.ca

Post-print version. Final published version available at: Parsons, K., Gaudine, A., \& Swab, M. (2018). Older nurses' experiences of providing direct care in hospital nursing units: a qualitative systematic review. JBI database of systematic reviews and implementation reports, 16(3), 669-700. https://doi.org/10.11124/JBISRIR-2017-003372 


\section{Executive summary}

\section{Background}

Most developed countries throughout the world are experiencing an aging nursing workforce as their population ages. Older nurses often experience different challenges then their younger nurse counterparts. With the increase in older nurses relative to younger nurses potentially available to work in hospitals, it is important to understand the experience of older nurses on high paced hospital nursing units. This understanding will lend knowledge to ways of lessening the loss of these highly skilled experienced workers and improve patient outcomes.

\section{Objectives}

To identify, evaluate and synthesize the existing qualitative evidence on older nurses' experiences of providing direct care to patients in hospital nursing units.

\section{Inclusion criteria}

Types of participants

Registered nurses 45 years and older who work as direct caregivers on any type of in-patient hospital nursing unit.

\section{Phenomena of interest}

The phenomenon of interest is the experience of older nurses in providing direct nursing care. This review excluded studies consisting entirely of enrolled nurses, licensed practical nurses, and licensed vocational nurses.

\section{Context}

The provision of direct nursing care on any type of in-patient hospital nursing unit (i.e., including but not limited to medical/surgical units, intensive care units, critical care units, perioperative units, palliative care units, obstetrical units, emergency departments, and rehabilitative care units.

Types of studies

Qualitative data including, but not limited to the following methodologies: phenomenology, grounded theory, ethnography, action research and feminist research.

\section{Search strategy}

A three-step search strategy was used. An initial limited search of the databases PubMed (MEDLINE), and CINAHL, was undertaken followed by an analysis of the text words contained in the title and abstract. A second search using all identified keywords and index terms within these databases was then undertaken across all included databases (CINAHL, Pub Med, PsycINFO, Embase, AgeLine, Sociological Abstracts and SocINDEX). The search for unpublished articles included Dissertation Abstracts International, MEDNAR, OpenGrey, OAlster, Google Scholar, and Google. Thirdly, the reference lists of included papers were then searched for any 
other relevant studies. Each database was searched from inception to October 13, 2017; no date or language limiters were applied.

\section{Methodological quality}

Each paper was assessed by two independent reviewers for methodological quality using the Joanna Briggs Institute Qualitative Assessment and Review Instrument (JBI-QARI). Any disagreements that arose between the reviewers were resolved through discussion.

\section{Data collection}

Data collection was conducted by two independent reviewers using the standardized qualitative data extraction tool from JBI-QARI.

\section{Data synthesis}

The qualitative research findings were pooled using JBI methodology. The JBI process of metaaggregation was used to identify categories and synthesized findings.

\section{Results}

Twelve papers were included in the review. Three synthesized findings were extracted from 12 categories and 75 findings. The three synthesized findings extracted from the papers were: (1) Love of nursing: It's who I am and I love it; (2) It's a rewarding but challenging and changing job; it's a different job and it can be challenging; (3) It's a challenging job, can I keep up?

\section{Conclusions}

Older nurses love nursing and have created an identity around their profession. They view their profession positively and believe their job to be unlike any other, yet they identify many ongoing challenges and changes. Despite their desire to continue in their role they are often faced with hardships that threaten their ability to stay at the bedside. A key role of hospital administrators to keep older nurses in the workplace is to develop programs to prevent work related illness and to promote health. Given the low ConQual scores in the current systematic review, additional research is recommended to understand the older nurses' experience in providing direct care in hospital nursing units as well as predicting health age of retirement and length of bedside nursing.

\section{Keywords}

Older nurses; direct care; hospital nursing units; experience; qualitative 


\section{ConQual Summary of Findings}

\begin{tabular}{|c|c|c|c|c|c|}
\hline Synthesized finding & $\begin{array}{l}\text { Type of } \\
\text { research }\end{array}$ & Dependability & Credibility & $\begin{array}{l}\text { ConQual } \\
\text { score }\end{array}$ & Comments \\
\hline $\begin{array}{l}\text { Love of nursing: it's who I am } \\
\text { and I love it } \\
\text { Older nurses love nursing and } \\
\text { feel that nursing and their } \\
\text { career as a nurse is a defining } \\
\text { factor in who they are as a } \\
\text { person. Older nurses providing } \\
\text { direct care in hospital nursing } \\
\text { units find their work and their } \\
\text { career rewarding. They have } \\
\text { been nursing long enough to } \\
\text { feel comfortable in the role and } \\
\text { are pleased by opportunities } \\
\text { they had for career } \\
\text { advancement and recognition. } \\
\text { They know they still have what } \\
\text { it takes to be a good nurse and } \\
\text { believe that nursing is about } \\
\text { caring for others and doing } \\
\text { right by their profession. } \\
\text { Nursing also helps them to feel } \\
\text { active and fulfilled. }\end{array}$ & Qualitative & $\begin{array}{l}\text { Downgrade } 1 \\
\text { level }\end{array}$ & $\begin{array}{l}\text { Downgrad } \\
\text { e } 1 \text { level } \\
\text { There } \\
\text { were a } \\
\text { mix of } \\
\text { unequivoc } \\
\text { al and } \\
\text { credible } \\
\text { findings }\end{array}$ & Low & $\begin{array}{l}\text { Downgraded } 2 \\
\text { levels due to } \\
\text { depend- ability } \\
\text { and credibility of } \\
\text { primary studies }\end{array}$ \\
\hline $\begin{array}{l}\text { It's a rewarding but } \\
\text { challenging and changing job } \\
\text { The nurses' experiences with } \\
\text { their work and workplace are } \\
\text { both positive and negative. } \\
\text { Their life is different because of } \\
\text { shift work. Although they feel } \\
\text { valued and appreciated they } \\
\text { sometimes feel discouraged, } \\
\text { for example, with their pension } \\
\text { benefits or because they feel } \\
\text { administration would like them } \\
\text { to retire. They see themselves } \\
\text { as different from younger } \\
\text { nurses whom they believe see } \\
\text { nursing as just a job, but } \\
\text { admire the assertive- ness of } \\
\text { the younger nurses. They note } \\
\text { many negative aspects of } \\
\text { nursing today, including how }\end{array}$ & Qualitative & $\begin{array}{l}\text { Downgrade } 1 \\
\text { level }\end{array}$ & $\begin{array}{l}\text { Downgrad } \\
\text { e } 1 \text { level } \\
\text { There } \\
\text { were a } \\
\text { mix of } \\
\text { unequivoc } \\
\text { al and } \\
\text { credible } \\
\text { findings }\end{array}$ & Low & $\begin{array}{l}\text { Downgraded } 2 \\
\text { levels due to } \\
\text { depend- ability } \\
\text { and credibility } \\
\text { of primary } \\
\text { studies }\end{array}$ \\
\hline
\end{tabular}




\begin{tabular}{|c|c|c|c|c|c|}
\hline $\begin{array}{l}\text { health care has become a } \\
\text { business. They are concerned } \\
\text { where nursing is going as a } \\
\text { profession. Some are still } \\
\text { working because they need the } \\
\text { money and the benefits. }\end{array}$ & & & & & \\
\hline $\begin{array}{l}\text { It's a changing job; can I keep } \\
\text { up? } \\
\text { Older nurses voice many } \\
\text { concerns; some have memory } \\
\text { problems, some are exhausted } \\
\text { with the ever-increasing work- } \\
\text { load, some are in pain, and } \\
\text { many have concerns if they can } \\
\text { move quickly enough in an } \\
\text { emergency. Others express } \\
\text { difficulty with changes in } \\
\text { technology. Despite all this, } \\
\text { they push themselves to } \\
\text { continue. Older nurses describe } \\
\text { both healthy and unhealthy } \\
\text { strategies they use to help } \\
\text { them continue working. }\end{array}$ & Qualitative & $\begin{array}{l}\text { Downgrade } 1 \\
\text { level }\end{array}$ & $\begin{array}{l}\text { Rated high } \\
\text { All studies } \\
\text { were } \\
\text { unequivoc } \\
\text { al }\end{array}$ & $\begin{array}{l}\text { Mode } \\
\text { rate }\end{array}$ & $\begin{array}{l}\text { Downgraded } 1 \\
\text { level due to } \\
\text { dependability of } \\
\text { primary studies }\end{array}$ \\
\hline
\end{tabular}

The ConQual approach ${ }^{1}$ was used to assess and report confidence in the results of this qualitative systematic review. The 12 studies included in this review were assessed for dependability. For synthesized finding 1, of the nine studies included, two addressed five of the dependability questions, two addressed four, four addressed three, and one addressed two. For synthesized finding 2, of the seven articles included, two addressed five of the dependability questions, one addressed four, and four addressed three. For synthesized finding 3, of the seven articles included, two addressed five of the questions, four addressed three, and one addressed two. Credibility of the findings was graded at three levels: those that could not be challenged were graded unequivocal $(U)$, those that could be challenged were graded credible (C), and those that could not be supported by data were graded unsupported (Unsupported) (Appendix I). The level of credibility of each finding was based on consensus between the two reviewers. 


\section{Introduction}

The majority of developed countries throughout the world have an aging population that corresponds with an aging nursing workforce. The average age of nurses in both Canada and the United States is 45 years. ${ }^{2,3}$ Ironically, despite an increase in the number of older nurses relative to younger ones potentially available to work in hospitals, the retirement of aging nurses has contributed to a critical global nursing shortage that is anticipated to increase.4 This global nursing shortage is in part due to a consistent pattern of nurses leaving hospital settings or the workforce after the age of 50 years. ${ }^{5}$

Older nurses leave the workforce early for a variety of reasons. First, direct care nursing in hospitals has long been known to be stressful for nurses. ${ }^{6}$ Work related stressors, including heavy workload, shift work, violence, increased acuity of patient care, and perceived lack of responsiveness to nurses' concerns, has led to an increase in work stress and job dissatisfaction. ${ }^{7}$ The level of job satisfaction has been determined to be highly predictive of employee turnover. ${ }^{8}$ Numerous predictors of job satisfaction amongst nurses have been identified and include: co- worker support, teamwork, retirement benefits, adequate equipment, healthcare benefits, open- door policy, respect from physicians and administrators, job security, shift of choice, paid time-off per year, educational opportunites, ${ }^{9}$ organizational commitment, perceived job alternatives, job search behavior, links with other employees, and sacrifices they would have to make if they left their current job. ${ }^{10}$ Furthermore, it has been reported that over $50 \%$ of registered nurses eventually experience burnout. ${ }^{11}$ In the 2006 white paper, Wisdom at Work: The Importance of the Older and Experienced Nurse in the Workplace, it was recommended that retention strategies for older nurses include flexible work options, workplace redesign and ergonomics, strategic management for demographic and workplace changes, training and lifelong learning, caregiver and grief resources, retirement planning and boosting participation in benefits, along with phased retirement. ${ }^{12}$

A second reason why older nurses leave the workplace prematurely is that older nurses themselves have cohort-specific health needs. Middle-age is a time of increasing likelihood of chronic disease ${ }^{13}$ as well as age-associated health changes such as a gradual decline in aerobic power, reaction time and acuity of the senses, and menopause symptoms. ${ }^{14,15}$ Furthermore, job-related morbidities such as musculoskeletal injuries, depression and chronic pain ${ }^{13}$ may further cause many older nurses to abandon their careers early.

The global health workforce is in a state of chronic, critical and worsening shortage, and is a fundamental constraint to reaching health and development goals. ${ }^{16}$ Nurses account for the largest proportion of this workforce. In an era of increased healthcare demands and a critical nursing shortage, it is important to understand the experience of older nurses in high paced hospital nursing units to lend knowledge on ways to lessen the loss of highly skilled experienced workers and to lessen negative patient outcomes. Patient outcomes have been directly linked with the number of registered nurse (RN) hours: more RN hours being associated with shorter patient hospital stays, and lower rates of upper gastrointestinal bleed, urinary tract infection, pneumonia and cardiac arrest. ${ }^{17}$ 
Very few studies have explored the experiences of older nurses providing direct care in hospital units. Friedrich et al. utilized a grounded theory approach to ascertain what motivates and inspires seasoned nurses to continue to practice in acute care after the normal age of nurse retirement. Four themes identified from the data were: existing attitudes and experiences, retention factors, important needs and unique contributions. ${ }^{18}$ Storey et al. conducted a crosssectional survey using a semi-structured questionnaire on nurses between 40 and 59 years $(78 \%)$ in different care venues, including hospital-based nurses. Results showed that older nurses were more likely than younger ones to report that their role had lived up to expectations. Older nurses reported that they wanted to be valued for the work they did and to be consulted regarding potential changes in the workplace. Furthermore they were more likely to stay if they received good pension advice, reduced working hours near retirement, and reduced workload. ${ }^{19}$ Muller et al. used a mixed-method design which included semi- structured interviews to demonstrate a positive relationship between the effects of selection, optimization and compensation on work ability in nurses between 21 and 63 years of age. ${ }^{20}$ Gabrielle et al., using a feminist perspective, interviewed 12 female nurses between the ages of 40 and 60 years to determine their health and aging concerns. Two major themes were identified: the aches and pains of aging and evolving lifestyles, and work in progress whereby exercise was seen as a health imperative in the light of existing constraints, such as chronic pain. ${ }^{21}$

In summary, only a limited number of studies have qualitatively addressed older nurses' experiences of providing direct care on hospital nursing units. A systematic review of studies on older nurses' experiences of providing direct care on hospital nursing units will therefore provide a single comprehensive set of synthesized findings. Also, a search of the JBI Database of Systematic Reviews and Implementation Reports, Cochrane Database of Systematic Reviews, CINAHL, PubMed and PROSPERO revealed no existing systematic reviews or protocols on this topic. This systematic review seeks to integrate the literature on the experiences of older nurses providing direct nursing care. Based on this, the review may also contribute to the development of retention strategies for older nurses in high-paced hospital nursing units.

This review was conducted according to an a priori published protocol. ${ }^{22}$

\section{Objectives}

The objective of this systematic review was to evaluate and synthesize the existing evidence on older nurses' experiences of providing direct care in hospital nursing units.

\section{Inclusion criteria}

\section{Participants}

Studies that included nurses both over and under the age of 45 years were included if findings for nurses 45 years and over could be separated from nurses under the age of 45 years. This review excluded studies that consisted entirely of enrolled nurses, licensed practical nurses and 
licensed vocational nurses. This is because registered nurses have a level of competence and skill that enables them to perform nursing competencies at a much different level than other such nurses, thus the nature of their nursing experience is most likely quite different.

\section{Phenomena of interest}

The phenomenon of interest was the experience of older nurses providing direct nursing care in in-patient hospital nursing units.

\section{Context}

This review considered studies that included registered nurses of any gender, culture or country, 45 years and over who worked as direct care nurses on any type of in-patient hospital nursing unit (i.e. including but not limited to medical/surgical units, intensive care units, perioperative units, palliative care units, obstetrical units, emergency departments and rehabilitative units.

\section{Types of studies}

This review considered studies that focused on qualitative data, including designs such as phenomenology, grounded theory, ethnography, action research and feminist research that explored the experiences of older nurses providing direct nursing care on in-patient hospital nursing units.

\section{Methods}

\section{Search strategy}

The search strategy aimed to find both published and unpublished studies. A three-step search strategy was used. An initial limited search of the databases PubMed (MEDLINE) and CINAHL was undertaken followed by an analysis of the text words contained in the title and abstract. A second search using all identified keywords and index terms was then under- taken across all included databases (CINAHL, PubMed, PsycINFO, Embase, AgeLine, Sociological Abstracts and SocINDEX). The search for unpublished articles included Dissertation Abstracts International, MedNar, OpenGrey, OAlster, Google Scholar and Google. Thirdly, the reference lists of included papers were then searched for any other relevant studies. Each database was searched from inception; the search was conducted on October 13, 2017; no date limiters or language limiters were applied.

\section{Information sources}

The databases searched included: CINAHL, PubMed, PsycINFO, Embase, AgeLine, Sociological Abstracts and SocINDEX.

The search for unpublished studies included: Dissertation Abstracts International, MedNar, 
Open- Grey, OAlster, Google Scholar and Google.

Initial keywords used were: nurses+, older nurses, hospitals+, "nursing staff, hospital", baby boomers, in middle age, middle aged, aging, age factors, employment of older workers, experienced nurs*, experiences, qualitative studies+, audio-recording, phenomenology, focus groups, narrative, observational methods, vignettes, interviews+, lived experience, bedside nursing

The full search strategy is provided in Appendix II.

\section{Assessment of methodological quality}

Qualitative papers selected for retrieval were assessed by two independent reviewers for methodological validity prior to inclusion in the review using the standardized critical appraisal instrument from the Joanna Briggs Institute System for the Unified Management, Assessment and Review of Information (JBI SUMARI). ${ }^{23}$ The two authors were able to reach consensus on any disagreements through discussion.

\section{Data extraction}

Qualitative data (i.e. illustrations and findings) were extracted from papers by two independent reviewers and included in the review using the standardized data extraction tool from JBI SUMARI. ${ }^{23}$ The illustrations extracted were the exact words of the study participants. Findings in the review articles were either labelled as themes or categories. In some cases, a finding was not specifically identified and in these cases the exact words of the authors that described the findings were pulled from the article. The data extracted included specific details about the interventions, populations, study methods and outcomes of significance to the review question and specific objectives.

\section{Data synthesis}

Qualitative research findings were pooled using JBI SUMARI. This involved the aggregation or synthesis of findings by consensus by both authors to generate a set of statements that represent that aggregation, through assembling the findings rated according to their quality, and categorizing these findings on the basis of similarity in meaning. These categories were then subjected to a meta-synthesis in order to produce a single comprehensive set of synthesized findings that could be used as a basis for evidence-based practice. Where textual pooling was not possible, the findings have been presented in narrative form.

\section{Results}

A comprehensive database search of the literature yielded 595 potentially relevant studies; 199 duplicates were removed. After review of the abstracts, 328 studies were excluded, leaving 68 articles being read in their entirety. From these, 54 articles were excluded because they did not 
meet the inclusion criteria. Fourteen studies were assessed and two were excluded due to insufficient methodological quality as outlined by JBI SUMARI. Twelve articles were included in this review. Appendix III provides details of the included studies. See Figure 1 for search results. Appendix IV describes the excluded studies and reasons for exclusion.
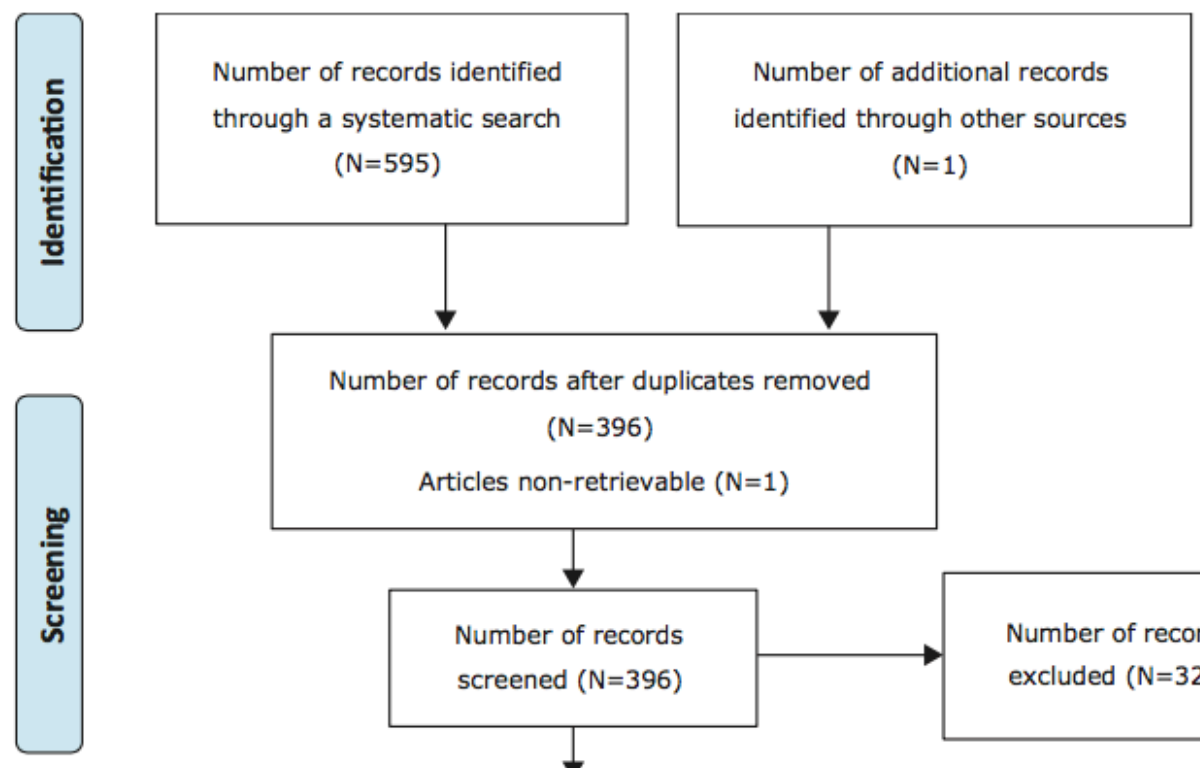

Number of records after duplicates removed

$$
(\mathrm{N}=396)
$$

Articles non-retrievable $(\mathrm{N}=1)$
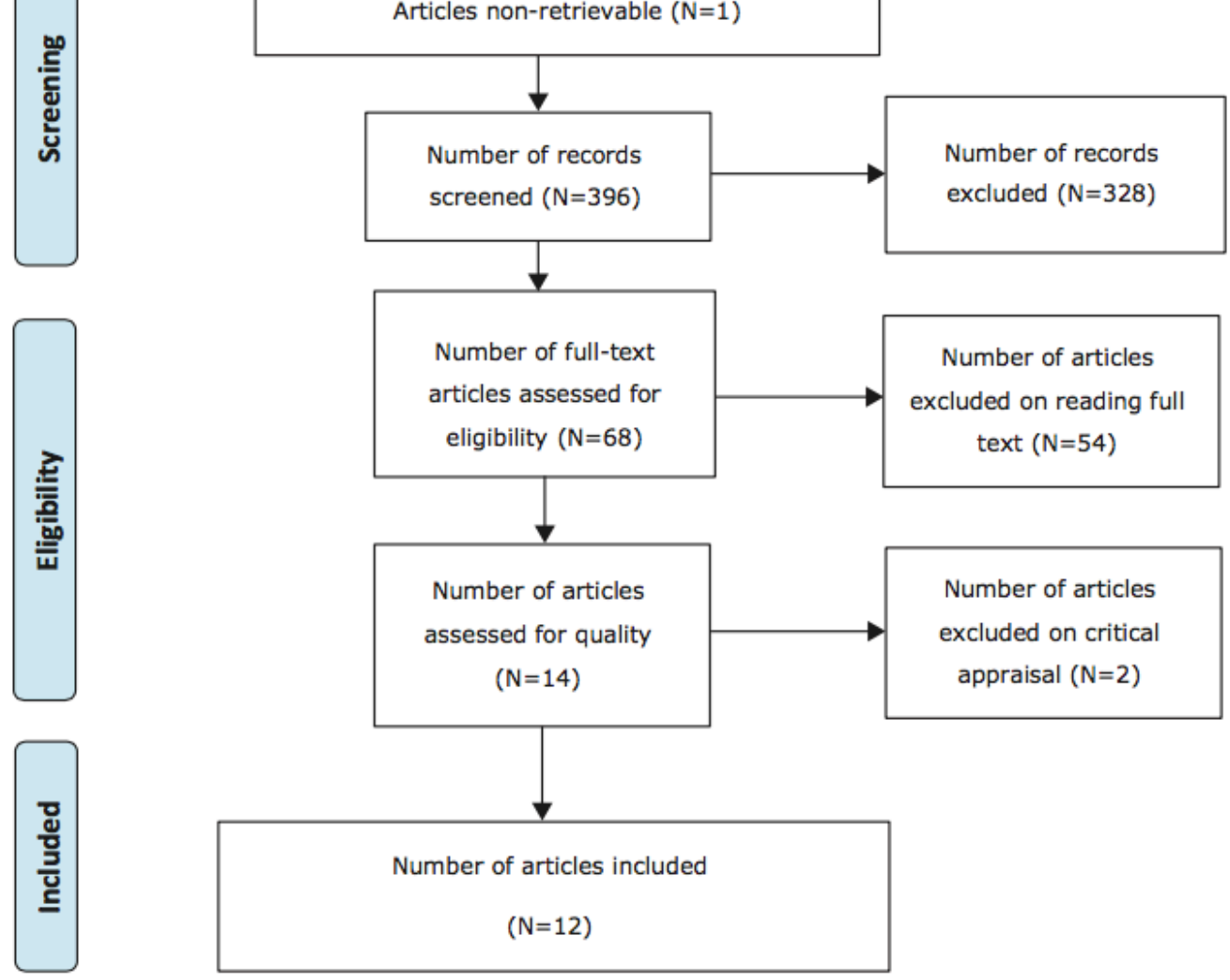

From: Moher D, Liberati A, Tetzlaff J, Altman DG, The PRISMA Group (2009). Preferred Reporting /tems for Systematic Reviews and Meta-Analyses: The PRISMA Statement. PLoS Med 6(6): e1000097.

Figure 1: Flowchart of study selection and inclusion process

\section{Methodological quality}

The studies included were qualitative in design and included findings pertinent to our systematic review. Table 1 summarizes the methodological quality of the 12 studies. Most of 
the criteria were met in the included studies. The two criteria that were least addressed were Q6 (There is a statement locating the researcher culturally or theoretically) and Q7 (The influence of the researcher on the research, and vice-versa, is addressed). For Q6 and Q7, only three and seven, respectively, of the 12 studies met these criteria.

\section{Characteristics of included studies}

The included studies provided data on the experience of being an older nurse providing direct patient care in hospital nursing units. Qualitative data from the included studies were analyzed using phenomenology, ${ }^{25,28,30,32,33}$ naturalistic inquiry ${ }^{29}$ and grounded theory. ${ }^{18,31}$ Several of the included studies ${ }^{24,26,27,34}$ did not state the specific qualitative method used. Sample sizes ranged from eight to 84 participants. The studies were carried out in the United States, United Kingdom, Australia and Finland.

Four of the studies included in this review directly explored the overall experience of being an older nurse $\mathrm{e}^{25-27,33}$ in direct patient care areas such as critical care and perioperative care. One study ${ }^{34}$ explored the perceptions, attitudes and beliefs of nurses about their professional competence, and another explored the experience of being an older nurse who suffered from depression and/or musculoskeletal pain. ${ }^{28}$ Five studies in this review specifically explored the factors that influenced older nurses in their decision to remain or not remain in nursing. ${ }^{18,24,29,30,32}$ Finally, Ultrianen et al. ${ }^{31}$ used grounded theory to create a substantive theory of well-being at work among hospital nurses.

Table 1: Assessment of methodological quality

\begin{tabular}{|c|c|c|c|c|c|c|c|c|c|c|}
\hline Citation & Q1 & Q2 & Q3 & Q4 & Q5 & Q6 & Q7 & $\mathrm{Q} 8$ & Q9 & Q10 \\
\hline Andrews et $a l^{24}$ & $U$ & $\mathrm{Y}$ & $\mathrm{Y}$ & $\mathrm{Y}$ & $\mathrm{Y}$ & $\mathrm{N}$ & $\mathrm{N}$ & $\mathrm{Y}$ & $\mathrm{Y}$ & $\mathrm{Y}$ \\
\hline Freidrich et al. ${ }^{18}$ & $U$ & $Y$ & $Y$ & $Y$ & $Y$ & $\mathrm{~N}$ & $\mathrm{~N}$ & $\mathrm{Y}$ & $Y$ & $Y$ \\
\hline Hodge $^{25}$ & $U$ & $U$ & $Y$ & $Y$ & $\mathrm{Y}$ & $\mathrm{N}$ & $Y$ & $\mathrm{Y}$ & $Y$ & $Y$ \\
\hline Letvak $^{26}$ & $Y$ & $Y$ & $Y$ & $Y$ & $Y$ & $\mathrm{~N}$ & $Y$ & $\mathrm{Y}$ & $\mathrm{N}$ & $Y$ \\
\hline Letvak $^{27}$ & $Y$ & $\mathrm{Y}$ & $Y$ & $Y$ & $Y$ & $\mathrm{~N}$ & $Y$ & $\mathrm{Y}$ & $\mathrm{Y}$ & $Y$ \\
\hline Letvak $^{28}$ & $Y$ & $Y$ & $Y$ & $Y$ & $N$ & $Y$ & $Y$ & $\mathrm{Y}$ & $\mathrm{Y}$ & $Y$ \\
\hline Sandy ${ }^{29}$ & $Y$ & $\mathrm{Y}$ & $Y$ & $Y$ & $\mathrm{Y}$ & $\mathrm{N}$ & $\mathrm{N}$ & $\mathrm{Y}$ & $\mathrm{Y}$ & $Y$ \\
\hline Thompson ${ }^{30}$ & $Y$ & $\mathrm{Y}$ & $\mathrm{N}$ & $Y$ & $\mathrm{Y}$ & $\mathrm{N}$ & $Y$ & $\mathrm{Y}$ & $\mathrm{Y}$ & $Y$ \\
\hline
\end{tabular}




\begin{tabular}{|l|l|l|l|l|l|l|l|l|l|l|}
\hline Ultrianen et al. $^{31}$ & $\mathrm{Y}$ & $\mathrm{Y}$ & $\mathrm{Y}$ & $\mathrm{Y}$ & $\mathrm{Y}$ & $\mathrm{Y}$ & $\mathrm{Y}$ & $\mathrm{Y}$ & $\mathrm{N}$ & $\mathrm{Y}$ \\
\hline Valencia et al. $^{32}$ & $\mathrm{Y}$ & $\mathrm{U}$ & $\mathrm{Y}$ & $\mathrm{Y}$ & $\mathrm{Y}$ & $\mathrm{N}$ & $\mathrm{N}$ & $\mathrm{Y}$ & $\mathrm{Y}$ & $\mathrm{Y}$ \\
\hline West $^{\text {et }}$ al. $^{33}$ & $\mathrm{Y}$ & $\mathrm{Y}$ & $\mathrm{Y}$ & $\mathrm{Y}$ & $\mathrm{Y}$ & $\mathrm{N}$ & $\mathrm{N}$ & $\mathrm{Y}$ & $\mathrm{Y}$ & $\mathrm{Y}$ \\
\hline Wheeler $^{34}$ & $\mathrm{Y}$ & $\mathrm{Y}$ & $\mathrm{Y}$ & $\mathrm{Y}$ & $\mathrm{Y}$ & $\mathrm{Y}$ & $\mathrm{Y}$ & $\mathrm{Y}$ & $\mathrm{Y}$ & $\mathrm{Y}$ \\
\hline$\%$ & 73 & 82 & 91 & 100 & 91 & 27 & 64 & 100 & 82 & 100 \\
\hline
\end{tabular}

\section{Findings}

Three synthesized findings were identified consisting of 12 categories and 75 findings. Appendix I provides a synopsis of the results of the meta-synthesis of the research findings.

\section{Synthesized finding 1: Love of nursing: It's who I am and I love it}

Synthesized finding one comprises four categories and 30 findings. Older nurses love nursing and feel as if nursing and their career as a nurse is a defining factor in who they are as a person. Older nurses providing direct care in hospital nursing units find their work and their career rewarding. They have been nursing long enough to feel comfortable in the role and are pleased by opportunities they have had for career advancement and recognition. They know they still have what it takes to be a good nurse and believe that nursing is about caring for others and doing right by their profession. Nursing also helps them to feel active and fulfilled.

\section{Category 1.1: Rewarding work and career}

Rewards around their love and satisfaction for the work itself, such as the interactions with and care for their clients, the ability to make a real difference in their clients' lives, as well as how the work makes them feel, create a positive self-image. The older nurses like the responsibility they have been given and thrive in the exciting environments where they continue to learn and share their wealth of experience with others, allowing them to make a unique contribution in the workplace.

\section{Finding 1: Rewarding career}

It is particularly rewarding to me when you actually see patients who could be discharged home who have improved to the point they were able to go home and have a functional life $e^{25(p .77)}$

Finding 2: Achievement (career/self and patient care) I have a talent that I worked to perfect. ${ }^{25(p .70)}$

Finding 3: Positive self-image - specific clinical focus My patients and their family trust me. I feel that how I care for them shows that I am a great critical care nurses who provides excellent and expert care. ${ }^{25(p .83)}$ 
Finding 4: Altruism is its own reward

Everything I do has my patients' best interest at heart. I do it only because I know I am doing it for my very ill patient. ${ }^{25}(p .86)$

Finding 5: Work itself

I like the care, I like the patients, I like the challenge, on [a] day-to-day basis there are challenges every day. ${ }^{25}(p .70)$

Finding 6: Responsibility

I want our patients to be given the best possible care; so therefore I want our new nurses to gain the confidence and experience needed to do that. ${ }^{25(p .70)}$

Finding 7: Interpersonal relations

Working in ICU gives me a chance to spend time with families in difficult times and encourage critically ill patients to help them through the process and to be helpful and give them excellent care. $^{25(p .71)}$

Finding 8: Self-perception

I'm the best I have ever been. ${ }^{34}$ (p.233)

Finding 9: Job satisfaction

At the end of the day, when I lay down in bed at night, I am satisfied. ${ }^{34(p .234)}$

Finding 10: We're here because we care

I love what I do. I know that I've done the best by my patients and nobody else may have done for them what I did. That's who I'm accountable to - the patient. ${ }^{26(p .50)}$

Finding 11: Learning/exciting environment

Program development is bringing a whole new set of technology. That's exciting. ${ }^{30}$ (p.581)

Finding 12: Nurse-patient interaction

That joy - even a smile that you can bring to a sick person's face is a THANKS - approval that gives strength to work. It is also a sign of a patient's trust. A touch - a light touch that a sick person is able to give to a nurse, his helper and promoter, in an expression of some deep approval, trust, caring... ${ }^{31(p .154)}$

Finding 13: Attitudes and experiences - wealth of experience I graduated in 1966 from a school of nursing in Minnesota that is no longer there. Then after graduation I worked in surgery for a year. I was putting my husband through seminary. We changed jobs quite a few times in those first few years. The next summer he wanted to go to summer camp, so I was a camp nurse. We moved back, and I worked 2 years in surgery. By then he had graduated, and we moved to a suburb, and I worked there in OB part-time. ${ }^{18(p .901)}$

Finding 14: Attitudes and experiences - love of nursing 
I just have a passion for nursing. I know it sounds crazy, but I just love going to work. ${ }^{18(p .901)}$

Finding 15: Unique contributions - sharing experience

I think one of the things I enjoy most is teaching. We teach the patients what to expect back in the pre-op room, the operating room, the recovery room, and what they could do to help themselves afterwards to take care of themselves the best after the surgery. ${ }^{18(p .903)}$

Finding 16: Unique contributions - making a difference It's just the satisfaction of making a difference in a patient that really needs your care. The personal care, the personal talks, and sometimes what a patient needs besides just getting over sickness or surgery, is to know you care. The caring aspect I would say that is no. $1^{\prime} .^{18(p .903)}$

Finding 17: Working for the satisfaction of connecting with patients and families I guess what I really enjoy is when you've got the time to talk to a patient and make a difference as opposed to just running around and completing the tasks the people are there to audit. I don't like to be in the mode of a waitress who comes with her little book to your table and says 'Can I help you' and doesn't even look at you. I don't want to be that kind of nurse. I don't want to be the nurse who walks in and says, 'You having pain? What is it, 1 to 10?' I want to be able to have the time to sit and look at the person. A lot of communication is not verbal. You can tell when someone's in pain. That gives me satisfaction. ${ }^{32(p .279)}$

Finding 18: Growing old in the OR

When I went into Fundamentals in nursing school in 1966, I distinctly remember the instructor going around and asking all of us what we wanted to do when we graduated. And all I wanted was to be in the OR. And I was the only one. I thought it would be exciting with a lot of action going on. And I was right. I loved it then, and I still do. ${ }^{27(p .641)}$

\section{Category 1.2: Career advancement and recognition}

After older nurses get to the top of the salary scale there are no additional incentives. Nurses believe they deserve more recognition because of the value they add to the hospital. They do, however, feel recognized by patients, families and other health professionals for their expertise and this brings them status. There are some opportunities for advancement.

Finding 1: Salary

When you get to the top of your pay scale you never get any extra incentives. ${ }^{25}(0.71)$

Finding 2: Recognition

Critical care nurses need more recognition because we make a difference in how the hospital is perceived by the families and our community. $\left.{ }^{25}(p .70)\right)$

Finding 3: Growth

There is the clinical ladder. $\left.{ }^{25}(p .71)\right)$ 
Finding 4: Status

The doctor will say for example, "I want an older ICU nurse, one who knows what they are doing."25 (p.71)

Finding 5: Perception by others

They respect me, my competence, and they respect my age. They trust me because I'm older. The physicians respect and trust me because they know me. ${ }^{34(p .233)}$

Finding 6: Preference of patients

I think the patients get a feeling of confidence and security in the fact that I am an older nurse, especially the older patients. . they are leery of a lot of the 'new medicine', and they look at me and think, she can do it, it must be all right. ${ }^{34(p .234)}$

Finding 7: Wanted to be treated with respect by the people she was interacting with and to have responsibility for projects

... was getting older and was looking for more challenges. ${ }^{29}(p .55)$

Finding 8: Hospital could not provide her the job satisfaction and creative outlets she required I knew acute care nursing did not feel right to me any longer; it didn't fit. ${ }^{29(p .75)}$

\section{Category 1.3: Doing right by the profession}

Older nurses feel they are loyal employees and have a strong work ethic. They recognize they need continuing education.

Finding 1: Professional behavior

I'm more loyal to the job, to the hospital that pays me. They deserve their money's worth. I feel like if I don't give it to them, then I am not being honest . . that work ethic is not prevalent today. ${ }^{34}(p .234)$

Finding 2: Education

I have to stay updated and know what is happening. I don't want to get behind on anything. ${ }^{34}$ (p.235)

\section{Category 1.4: Keeps me active}

Working keeps the older nurses busy, and their mind and body active, and prevents boredom.

Finding 1: Important needs - exercising mind and body

I love keeping busy. I have a lot of peers who have retired and they just age is what I see. Your world becomes more closed in if you don't stay busy. ${ }^{18(p .902)}$

Finding 2: Working to avoid boredom

I think for me being single, with no family or children at home, my thoughts on retirement are that if I retire, I'm going to become bored and won't have a lot to do. Although I do travel a lot and I like to meet people, and keep busy, I can't imagine not helping people. So my thoughts 
when I retire are to volunteer. I see a lot of retired people get depressed and then sit there bored. You have to do something more than just filling in the time, other than sitting there and watching the soaps all day. I find I have a need to do something that's constructive. ${ }^{32(p .283))}$

\section{Synthesized finding 2: It's a rewarding but challenging and changing job}

Synthesized finding 2 comprises five categories and 30 findings. The nurses experiences with their work and workplace are both positive and negative. Their life is different because of shift work. Although they feel valued and appreciated they sometimes feel discouraged, for example, with their pension bene- fits or because they feel administration would like them to retire. They see themselves as different from younger nurses whom they believe see nursing as just a job. They do however, admire the assertiveness of the younger nurses. They note many negative aspects of nursing today, including how health care has become a business. They are concerned where nursing is going as a profession. Some are still working because they need the money and the benefits.

\section{Category 2.1: Relationship with the workplace}

Both positive and negative relationships with the organization are experienced by older nurses. They feel appreciated and valued for their expertise and the work they do. Older nurses know that they are capable of caring for challenging patients, and note that they are often called upon to do this. Because of their expertise, they are more than able to carry their own workload. They enjoy working with other nurses and teamwork, and the feeling of having a second family. They feel supported by their colleagues and having their input valued by them. The older nurses continue to learn new things, with each day bringing something new. They appreciate the need to continue learning and that, through their learning, they are able to teach others. Feeling comfortable in their practice area helps them remain in their workplace.

Finding 1: Our relationship with the organization

I receive very positive feedback from my manager. She is always making little comments such as, you aren't getting ready to retire. Period. You can forget it. And that thrills me. I'm glad she feels that way. ${ }^{26(p .52)}$

I think they want to keep me for the slot I fill, but I also think they would love to get rid of me. But they need me. ${ }^{26(p .52)}$

Finding 2: Good relationships with team members

They care about staff..$^{30(p .580)}$

Finding 3: Nurse-nurse interaction

I felt it as very positive that they (younger nurses) trust me so much, I can sense that they like to ask me and get guidance, I think it is an expression of trust and it gives me strength. ${ }^{31(p .153))}$ The climate on our unit is 'open' and quite inclusive, in other words, we dare to express our feelings and we really do that. In our place we dare to laugh and cry. ${ }^{31(p .153))}$

Finding 4: Team support - supportive relationships are important

Coming into work, you're walking a little bit funny, your coworkers are, 'Oh, you got back pain 
today don't ya?' 'Yeah, I do. 'That makes me feel a little better right there because they're recognizing it. ${ }^{28(p .12-13)}$

Finding 5: Attitudes and experiences - culture of the workplace You can't do it yourself. I really believe on the floor where I work that there is a lot of good teamwork and that we do support and help each other. ${ }^{18(p .901)}$

Finding 6: Important needs - camaraderie

The camaraderie of the peers that you work with - it really becomes your second family. I enjoy that part. $^{18(p .921)}$

Finding 7: We carry our load I don't get an easier assignment because I'm over 50. I carry my own weight. Sometimes they give me the most difficult patients. ${ }^{26(p .50)}$

Finding 8: Attitudes and experiences - appreciation of learning Every day is different so you have to learn. You can't be stuck on what you learned before, because you have to change. ${ }^{18(p .901)}$

Finding 9: Retention factors - reduced pressure role

For me, working in special care nursery is better now that I'm older because I don't have to run up and down the halls. I'm 73 years old, and I'm not as speedy as I used to be. ${ }^{18(p .902)}$

\section{Category 2.2: It's a different time}

The older nurses see recent nurse graduates as different from them. They see younger nurses as not wanting to be at the bedside or wanting to leave nursing completely. They also see younger nurses as being more assertive and believe this is a good thing.

Finding 1: Our relational workplace

There are lots of differences between the nurses we are preparing now. When I graduated from nursing school I knew I was going to be a nurse forever. These nurses can only talk about how soon they can go back to school and get away from the bedside or they just want to leave nursing completely. ${ }^{26}$ (p.51)

Finding 2: Multiple temporalities - the intergenerational workplace They've got more realistic expectations than they had when I started training. You had to jump, if they said jump six feet we had to jump six feet. We don't have to jump six feet now and I guess that's the changing environment of nursing too 'cause I found it interesting I've got a daughter who's a nurse and she is very assertive and actually she's taught me heaps on assertiveness and it's good. . I like, I like my daughter's attitude to work. She's still a very caring nurse, excellent nurse, but she just knows where the boundaries are. ${ }^{33(p .117)}$

Finding 3: Conflict - younger nurses I have really reserved my comments to the young nurses who have come to work in my critical 
care unit. You only have to see them roll their eyes at you once to know they don't value what I have to say or want to show them. ${ }^{25(p .80)}$

\section{Category 2.3: Negative aspects of work}

The older nurses are not satisfied with hospital policies. As well, they have concerns about how nursing has changed, such as time spent away from patients to work on computers. They voice concerns about their schedule, having to be on call and how it is difficult if they have children and/or elderly parent responsibilities. The frequency of change makes them question if all the changes are necessary and also makes them think about retirement. One change older nurses have noted is that health care has become a business. They state that their experience and compassion, and the quality of their patient care are not as valued by administration. Nurses are saddened by how the shortage of nurses is changing their work life. They are worried about how the increasing shortage of nurses would impact the future of nursing. They are concerned about the lack of compassion of younger nurses.

Finding 1: Company policy/administration

Hospital policies, no I am not satisfied. ${ }^{25(p .72)}$

If there is a problem with a person, just deal with that person and not make a rule because of it. $^{25(p .72)}$

Finding 2: Working conditions

I spend more time nursing the computer than I do my patients. ${ }^{25(p .72)}$

I wish that management would look at and change moving patients in and out. ${ }^{25}$ (p.72)

Finding 3: Interpersonal and organizational concerns

Hospitals must be more flexible. We paid our dues, and we need a little time with our older parents and our grandchildren. A lot of older nurses just might stay in longer if they didn't have to worry about call. ${ }^{27(p .644)}$

Finding 4: Predictability is motivating/change creates dissatisfaction I think there are just too many changes. You get all these nursing classes that say to implement change in stages so it can be assimilated. But here you change and you change and you change and you change. It doesn't ever stop. This amount of change makes me think about retiring. Some degree of predictability in my job would keep me working. ${ }^{32(p .280)}$

Finding 5: Team support - a lack of administrative support They don't even want to know. Acknowledge I guess would be the better thing to say. To acknowledge that we have a value and that they need to help us look for places within the organization that we can still use our expertise and still be productive nurses rather than just saying, "Oh that's all right, she can't do this anymore, bye."28(p.13)

Finding 6: EMR, technology, and equipment changes are upsetting/challenging Does all this change really help? I know they're trying to improve but the change is non-stop. There are people that say, 'Well, keep up or get out.' I've heard that. The amount of new 
technology makes me think about retiring. Like the other day we got new central station monitors. Every time you want a two-channel recording, you have to go and reprogram it, because it wasn't configured to do that. I called Clinical Engineering and asked if there's anyone who could provide an in-service because there were nine nurses working who didn't know how to do it. I had looked at the two-hour videotape about a month ago, and they were like, 'No, no one's here, no one can come, sorry.' I'm like, 'Okay.' That's not a way to retain nurses. ${ }^{32(p .281)}$

Finding 7: Conflict - administration

Administration could care less that I have been a critical care nurse for 36 years. In fact, if I left they would look at it as a cost saving and would bring an inexperienced nurse in to save money. ${ }^{25(p .81)}$

Finding 8: Hospital administration mandating an increase in cost cutting measures ... overwhelmed with all the responsibility. I no longer felt I was doing what I perceived nursing to be or able to deliver quality care to the patients. Instead I was involved in meeting state and other regulatory standards and managing aspects of the organization that were far removed from patient care. ${ }^{29(p .54)}$

Finding 9: Could not continue to manage The responsibilities and number of patients each nurse was assigned were becoming unmanageable. ${ }^{\prime 29(p .57)}$

Finding 10: Worries about the future We are bringing in some new young nurses, but our directors are not prepared to educate them, and we don't have educators. Our education programs are all CBL [computer-based learning] that's great but who are these young girls going to ask a question of $?^{27}(p .646)$

Finding 11: 'Push' factors - pace of technological change

We have been smothered with computers and printers, and I am just overwhelmed at the thought of using them. ${ }^{24(p .302)}$

\section{Category 2.4: Money/benefits}

Older nurses speak of needing to work for money and benefits. They have concerns that the benefits they believe they have may change. They want to work until they are certain they will have a secure future.

Finding 1: Important needs - finances

The other thing that kept me in nursing was the money; because if I'm retired, I have to buy my insurance. So I work to pay my monthly insurance so I don't have to take it out of my pension. ${ }^{18}$ (p.902) (p.54)

Finding 2: Concern over changing benefits

I am very concerned about pending changes that could affect my retirement. I felt like after all the years I have worked I would have lifetime medical benefits but it seems that could change. 
I'm very concerned about that because I don't perceive Social Security having as much money as it needs to. Medical plans are not what they used to be. The prescription drugs are much higher. I take two prescription drugs, and it's very expensive. Right now, I'm spending over $\$ 100$ a month for those drugs. I can handle that, but I can't imagine when I'm retired how I would manage. Those are the worries that keep me from retiring. ${ }^{32}$ (p.275)

Finding 3: Working for financial security

I'm trying to put as much as I can into my 403(b). I'm hoping I can work until my house is paid off, so that would be close to 65. I'm the only one in the family except my kids. I don't want my kids to feel they have to support me. That's one of the reasons I want to work as long as I can and stay as active mentally as I can. I want to feel I'm in a good position financially and able to take care of myself. ${ }^{32(p .275)}$

Finding 4: 'Pull' factors - financial influences on older nurses .. financial considerations and the fact that if I left too early my pension would be affected. ${ }^{24}$ (p.303)

\section{Category 2.5: A different life}

Because nursing involves shift work, the older nurses speak about how they have a different family life because they are working at times when the rest of their family is together. They feel exhausted sometimes when they need to shuffle their schedule to see family/ people and keep appointments. They can be less close to their family and extended family because of not seeing them frequently.

Finding 1: Multiple temporalities - temporality and the concept of multiples Hard work, long hours, you're married, you've got children, you're trying to shuffle your home life and your work life and I guess at the end of the day there's not a lot of time for yourself and you're just dog tired most of the time. ${ }^{33(p .114)}$

Finding 2: Multiple temporalities - arranging life around shift work Shift work is actually a very good thing because it gives you flexibility in your life and the places that I've worked you've had a choice of setting up your own roster so therefore the idea of that, the optimum of that, is that you can have a life outside of your workplace because you've set the dial. In reality [laughing], the reality is that from day to day in my workplace at the moment which is in a very busy day surgery unit we have three different shift times. ... I'd forgotten all about phoning in and then I thought no look I know what I'm doing and then arrived at 6.15 to start on the shift to be told, "Oh what are you doing here? You're not here until 7.30". Which meant of course that at the end of the day I was expected to be here longer which didn't suit. ${ }^{33}$ (p.115)

Finding 3: Multiple temporalities - social effects

it's a family network and the sibling relationships that you miss out on because you know you're doing such and such and your brother and sister go off and do something every other week that you might get to once in a blue moon and then you don't fit in because even with your family 
you'd missed that continuity. My children aren't as close to their cousins as my brother's and sister's children are. My children walked past their cousin in the street and didn't recognize her. . .. they didn't know her and she didn't know them either but you know that wouldn't have happened if we'd been every Saturday afternoon drinking at the pub or whatever. ${ }^{33(p .116)}$

\section{Synthesized finding 3: It's a changing job; can I keep up?}

Synthesized finding 3 comprises three categories and 15 findings. Older nurses voice many concerns; some have memory problems, some are exhausted with the ever-increasing workload, some are in pain and many have concerns if they can move quickly enough in an emergency. Others express difficulty with changes in technology. Despite all this, they push themselves to continue. Older nurses describe both healthy and unhealthy strategies they use to help them continue working.

\section{Category 3.1: Needing to be physically and/or mentally fit}

The nursing workload is exhaustive, although most of the older nurses can keep up but this can be at the cost of their well-being. Some find their memory is not as good as it has been. Some find they walk slower and fear this could be a problem if there is an emergency. They prefer working in areas where there are fewer physical demands or shorter shifts. They want to find strategies that will keep them feeling healthy and able to work. They wish management would find strategies that would help them to be able to stay in the workplace.

Finding 1: Energy level

The young ones can't outwork me, I run up and down the halls. ${ }^{34}$ (p.234)

Finding 2: Memory

I'm no more forgetful than the younger nurses. ${ }^{34 \text { (p.234) }}$

I don't think as fast as I used to. . . The knowledge is there, and age has not affected my ability to act in a crisis, but it takes longer to speak out. ${ }^{34 \text { (p.234) }}$

Finding 3: My practice of nursing changed - moving slowly

I just walk slower than many other nurses. Just walking slower, a lot of our time is spent walking to and from rooms and nursing stations and just my walking time slows me down because I don't walk as fast. ${ }^{28(p .11)}$

Finding 4: My practice of nursing changed - patient safety concerns I'm slower and I guess that could be a real big thing if, like, a baby was choking in a room. I couldn't get there as fast as someone who didn't have any problems. I don't run. ${ }^{28(p .11)}$

Finding 5: Retention factors - retention strategies For me, working in special care nursery is better now that I'm older because I don't have to run up and down the halls. I'm 73 years old, and I'm not as speedy as I used to be. ${ }^{18(p .902)}$

Finding 6: Retention Factors - less physical challenges

Doing some of the procedures like I.V. would be fine, but not the heavy, physical work. It's too 
exhausting for the older nurse. ${ }^{18(p .902)}$

Finding 7: Concern about staying healthy prompts nurses to consider retirement If my body holds up I will stay. I might have to work 8 hour shifts or something. I would consider lunch relief or the clinic. I just don't know if I could work the 12 hours on my feet, running, or else I might have to change my way of operating, my way of being. If I had a place where I'd be close to my patients and I could eat that would be one thing that would motivate me to work longer. Being able to exercise more would keep me here. Having ways to keep healthy and physically stimulated and also doing mind-stimulating techniques would keep me here. I would like to take some classes outside of nursing. I would love to do ballroom dancing. And then just doing maybe some yoga and Pilates exercises just to stretch and strengthen would be good. I think hospitals should offer health options for nurses like wellness programs. We need to stay healthy while we work. ${ }^{32(p .282)}$

Finding 8: 'Push' factors - stress and older workers I decided to take early retirement basically because I had a very stressful year. . we were short staffed.24 (p.303)

Finding 9: 'Pull' factors - flexible working hours for older nurses .. felt that a full-time service, 37.5 hours at age 55, was definitely too much. ${ }^{24(p .303)}$

Finding 10: Multiple temporalities - constructing a personal temporality I guess as time goes on if I find that I'm just getting way, way too tired which is one of the reasons why I've cut from eight to seven (shifts). . . I was just exhausted and I remember commenting to my husband and saying I don't know how much longer I can keep this up I'm just tired all the time. . I was stopping doing things that I enjoyed. . I think I've become probably more a homebody than a person that goes out a lot . . now I just think oh I couldn't be bothered I just want to veg. . . I'll just keep dropping days until I find that I've reached somewhere where I'm not feeling tired and I can come to work and do my few days work and feel okay. I don't particularly want to give it up altogether I'm not ready for that yet... ${ }^{33(p .1173)}$

Finding 11: Totally exhausted ...burned out. ${ }^{29(p .68)}$

\section{Category 3.2: Physically and mentally too hard}

Nurses say they experience a lot of pain from the physical work. Sometimes the pain is excruciating but they continue to push themselves to make it through the day.

Finding 1: A daily struggle - it hurts every day Sometimes they've had to take me to my car in a wheel chair at the end of my 13-hour shift and then I came back and worked the next day. ${ }^{28(p .10)}$

I am always very sad. What I had. What I used to do. Now I'm not suicidal or anything but so many days I am at work and am just so sad. ${ }^{28(p .10)}$ 
Finding 2: A daily struggle - inner strength and courage

I get up in the morning hurting. "OK, I got to make it through this day. I know it's going to hurt, I don't feel good but I'm going to work." So I do. I do my job. Those patients need me. That is what keeps me going. ${ }^{28(p .11)}$

\section{Category 3.3: Working around their deficits}

Older nurses describe different strategies they use to help them continue working. They also describe unhealthy strategies they use to stay in the workplace.

Finding 1: Learning to cope - positive coping strategies

I've been a preceptor for years and I'd rather do that than even go into administration because I am not a confrontational person. I'm more the nurturer, take care of person. So, practically since I've started here, I've been precepting people. Almost on an ongoing basis, which helps me because I do have that extra pair of hands where you're usually doing a lot of physical part of the work, you know, and I can help them more with the cognitive area. ${ }^{28(p .12)}$

Finding 2: Learning to cope - negative coping strategies

Well I cope by clocking out, staying late. I never get out on time. ${ }^{28(p .12)}$

\section{Discussion}

This review aimed to synthesize the best available evidence of the experience of older nurses providing direct care in hospital nursing units. Using JBI SUMARI, three synthesized findings were identified consisting of 12 categories and 77 findings. The three synthesized findings are: 1) Love of nursing: it's who I am and I love it, 2) It's a rewarding but challenging and changing job, and 3) It's a changing job; can I keep up?

The experience of older nurses providing direct care in hospital nursing units is an important topic for a systematic review because there is an aging workforce in many countries, a shortage of nurses and consequently, a need to keep older nurses in the workplace. Despite efforts to address the RN short- age in Canada, the Canadian Nurses Association (CNA) predicts this shortage will rise to approximately 60,000 by the year $2022 .{ }^{35}$ The report points out that keeping nurses in the profession is also an important part of building Canada's RN workforce. If the annual loss of RNs under the age of 60 is less than two percent, and the loss of those 60 or over is no more than $10 \%$, then 30,000 full-time nurses would effectively be added to Canada's nursing supply, cutting the shortage in half over 15 years. This is the first systematic review on this topic of growing importance. The review synthesized 12 studies and our three overarching synthesized findings provide the best overview of knowledge on this topic.

The first synthesized finding, Love of nursing: it's who I am and I love it, indicates that older nurses who remain in direct care in hospital settings are there because they love nursing. Moreover, they are there because being a nurse is part of their identity; it is who they are. This finding is similar to what is known about why people enter the nursing profession, and why nurses are motivated to remain in the nursing profession. Further, this finding is related to what 
is known about professionals developing a professional identity. Professional acculturation into the nursing profession of novice nurses is complex, taking years to navigate ${ }^{36}$ and the accumulative effect of socialization and skill acquisition is positively influenced by caring relationships with colleagues and patients. In a qualitative study of 60 nurses over five countries, Malloy et al. ${ }^{37}$ asked nurses how they found meaning in their very challenging work and discovered that the relationships among the nurses and with their patients, families, community and workplace were central to meaningful work. These compassionate caring relationships strengthened the nurses' commitment to their profession over time and created a sense of personal identity.

In a study of nursing students $(N=29)$, direct care nurses $(N=25)$ and nurse managers $(N=10)$, Newton et $a{ }^{38}$ identified four themes related to what motivated nurses to enter and stay in nursing that were commonly held by the nursing students and nurses. These themes were: a desire to help, caring, sense of achievement and self-validation. Self-validation or the desire to feel good was a new finding in the literature on nurses' motivation. Our first synthesized finding includes the love of nursing, and this love of nursing and what nurses do is similar to selfvalidation or the desire to feel good, thus supporting this new finding in the literature.

The second synthesized finding, It's a rewarding but challenging and changing job, shows that older nurses who remain in direct care in hospital settings found the nature of their work rewarding and that they enjoy managing challenges and changes. This finding encompasses the positive and negative impact of the workplace on the older nurse including issues around coworkers and supervisors. The nursing literature on quality of work-life issues reflects this theme in the general population of nurses. The literature on magnet hospitals ${ }^{39-42}$ provides an in-depth description of positive features of hospital workplaces. These features include support from supervisors and coworkers, effective leadership, and manageable workload. ${ }^{41,42}$ Nurses working in magnet hospitals have higher satisfaction ${ }^{43}$ and lower turnover ${ }^{44}$ than nurses working in non-Magnet hospitals.

In contrast, there has been much research on the impact of poor work environments on nurses. Multiple work stressors have been identified in research on hospital nurses including workload, ethical conflict ${ }^{45}$ working shifts, ${ }^{46}$ patient acuity ${ }^{47}$ and violence among nurses. ${ }^{48}$ Work stress has long been established as a predictor of low job satisfaction, poor health, and high turnover. ${ }^{49,50}$ It can be extrapolated that if work stress predicts poor health and turnover in the general work force, older nurses may be particularly impacted and this may lead to retirement.

The third synthesized finding, It's a changing job; can I keep up? shows that older nurses are facing challenges in managing their work and question if they will be able to continue to fulfill their responsibilities. Some of the nurses continue working at a great physical and mental expense to themselves because they need the salary or benefits such as health care. Other nurses continue working because they want to, but fear they may not be able to continue with the demands. There has been much research on the impact of shiftwork on the physical health of the shiftworker. Shiftwork syndrome or shiftwork disorder is described as a disruption of the circadian sleep/wake cycle, resulting in insomnia sleepiness and fatigue. ${ }^{51} \mathrm{~A}$ study that included 
interviews with 84 nurses over the age of 50 who were employed, retired, or thinking of returning to work, identified that these nurses found the pace of work and the physical requirements of their work challenging. ${ }^{52}$ This finding is similar to our third synthesized finding that includes the nurses' fear: "Can I keep up?"

This synthesized finding identifies that older nurses are challenged by their work and having difficulty in keeping up. This finding is also evident in literature about nurses who are younger. The issue of nurse fatigue is defined as: ". . . a subjective feeling of tiredness that is physically and mentally penetrative. It ranges from tiredness to exhaustion, creating an unrelenting overall condition that interferes with individuals' physical and cognitive ability to function to their normal capacity." 53 (p.1)

Given the working conditions of direct care nurses in todays' health care contexts, it is likely that nurses experience fatigue. This may be particularly the case for older nurses.

There is no question that the increases in technology, including nursing informatics combined with escalating health care costs and budget cuts, have changed the reality of nurses' work. As well, recent publicity about patient safety has added to nurses' stress in that they fear they may cause harm to a patient. ${ }^{54}$ Nurses also have increased knowledge about ethical issues and their ethical conflicts have been found to increase their stress ${ }^{45}$ and stress is known to predict turnover ${ }^{55}$ which may be evidenced as retirement in the older nurse.

\section{Strengths and limitations}

A strength of this systematic review is that it includes 12 studies. A limitation of this review is that while every attempt was made to include all relevant studies, it is possible that some were missed. In addition, only English studies were included. Further, the ConQual assessment for two of the three synthesized findings is low, indicating the dependability and credibility of the studies reviewed were low. Henceforth, any recommendations are also lowered in their applicability.

\section{Conclusions}

Older nurses love nursing and have created an identity around their profession. They view their profession positively and believe their job to be unlike any other yet they identify many ongoing challenges and changes. Despite their desire to continue in their role they are often faced with hardships that threaten their ability to stay at the bedside. Given the low credibility of some findings, the grade of related recommendations is also low. However, we make the following recommendations:

\section{Recommendations for practice}

Several recommendations for practice emerged from the review. Synthesized finding 3 suggests that older nurses differ from their younger nurse counterparts because of a number of 
physiological and sociological changes that result from a higher prevalence of morbidities (e.g. musculoskeletal injuries, depression and chronic pain ${ }^{13}$ ). Keeping in mind that older nurses may be more susceptible to change further compounds the problem. The aging nursing workforce has become an increasingly important occupational health issue. Occupational health must play a key role in the nursing workplace. Health promotion programs need to start early, before workers get older, before the age of 45 , and address the challenges of the aging workforce, including the prevention of work-related illnesses.

Because being rewarded can affect commitment to the organization, nurse managers must foster mutual trust with nurses and develop incentives such as flexible working hours or preceptor positions for older nurses that promote respect for the condition of the older nurse. Management and peer support is crucial and nurse management has the responsibility to foster positive relationships between older and younger nurses. Older nurses must feel supported and safe to voice their concerns. Examples include providing rest areas for RNs when they feel exhausted or are experiencing pain and where they can feel safe in communicating openly. ${ }^{56}$ Learning needs assessments that lead to more age sensitive training in the areas of technological change need to be considered. Employers need to recognize the need to provide older nurses with sufficient education to ensure they are comfortable with technology in the workplace.

\section{Recommendations for research}

Given the ConQual scores, additional research is recommended on the experiences of older nurses providing direct patient care in hospital nursing units, in particular, research that explores how age of retirement and length of bedside nursing affect the health of nurses and their ability to adequately provide the necessary care to their patients. Furthermore research needs to be conducted to explore and evaluate the effectiveness of different kinds of health promotion strategies on age of retirement.

\section{Acknowledgements}

The authors would like to acknowledge the support of the Queen's Collaboration for Health Care Quality: a Joanna Briggs Institute Center of Excellence. 


\section{References}

1. Munn Z, Porritt K, Lockwood C, Armataris E, Pearson A. Establishing confidence in the output of qualitative research synthesis: The ConQual approach. BMC Med Res Methodol 2014;14(9):108.

2. Canadian Institute of Health Information, [CIHI]. Regulated nurses Canadian trends, 2007 to 2011. [internet] 2014. [cited 2014 October15]. www.https://secure.cihr.ca/free_products/Regulated_Nurses_EN.pdf.

3. Health Resources and Services Administration, Bureau of Health Profession. National Center for Health Workforce Analysis April 2013. The US nursing workforce: Trends in supply and education. [cited 2014 October 15] Available from: https://www.ruralhealthinfo.org/pdf/nursing-work- force-nchwa-report-april-2013.pdf.

4. Sherman RO, Chiang-Hanisko L, Koszalinski R. The aging nursing workforce: a global challenge. J Nurs Management 2013;21(7):899 - 902.

5. Rosenfeld $P$. Workplace practices for retaining older hospital nurses: implications from a study of nurses with eldercare responsibilities. Policy, Polit, Nurs Pract 2007;8(2):120 - 9.

6. Watson R, Gardiner E, Hogston R, Gibson H, Stimpson A, Wrate R, et al. Occupational health and well-being. A longitudinal study of stress and psychological distress in nurses and nursing students. J Clin Nurs 2009;18(2):270 - 8.

7. Bogossian F, Winters-Chang P, Tuckett A. "The Pure Hard Slog That Nursing Is..." A qualitative analysis of nursing work. J Nurs Schol 2014;46(5):377 - 88.

8. Lambert EG, Hogan N, Barton SM. The impact of job satisfaction on turnover intent: A test of a structural measurement model using a national sample of workers. Soc Sci J 2001;38(2):233- 50.

9. Kuhar PA, Miller D, Spears SM, Ulreich SM, Mion LC. The Meaningful Retention Strategy Inventory. J Nurs Adm 2004;34(1):10 - 8.

10. Holtom BC, O'Neill BS. Job Embeddedness: a theoretical foundation for developing a comprehensive nurse retention plan. J Nurs Adm 2004;34(5):216 - 27.

11. Laschinger HKS, Flnegan J. Empowering nurses for work engagement and health in hospital settings. Nurs Economics 2005;35(10):439 - 49.

12. Hatcher BJ, Bleich MR, Connolly C, Davis K, O'Neill H, Hill KS. Wisdom at work: The importance of the older and experienced nurse in the workplace. [internet] 2006. [cited 2014 August 10] Available from: http://www.rwjf.org/content/ dam/supplementaryassets/2006/06/wisdomatwork.pdf. 2006.

13. Rosenfeld JA. Introduction. In: Rosenfeld JA, editor. Women's Health in mid-Life: A Primary Care Guide. Cambridge: Cambridge University Press, 2004.

14. Shephard RJ. Aging and productivity: some physiological issues. Intl J Indust Ergon 2000;25(5):465-75.

15. Gradison M. Physical changes in menopause and Perimenoapause. In: Rosenfield JA, editor. Women's Health in midlife: A Primary Care Guide. Cambridge: Cambridge University Press, 2004.

16. WHO. [Internet] 2014. [cited 2014 October 29]. Available from:

Http://www.who.int/workforcealliance/documents/GHWA-Lusaka.pdf. 2006 JBI Database System Rev Implement Rep 2015; 13(5) 87 - 96.

17. Needleman J, Buerhaus P, Mattke S, Stewart M, Zelevinsky K. Nurse staffing levels and 
quality of care in hospitals. N Engl J Med 2002;346(22):1715 - 22.

18. Friedrich LA, Prasun MA, Henderson L, Taft L. Being a seasoned nurse in active practice. J Nurs Management 2011;19(7):897 - 905.

19. Storey C, Cheater F, Ford J, Leese B. Retaining older nurses in primary care and the community. J Adv Nurs 2009;65(7): 1400 - 22.

20. Muller A, Weigl M, Heiden B, Herbig B, Glaser J, Angerer P. Selection, optimization, and compensation in nursing: Exploration of job-specific strategies, scale development, and agespecific associations to work ability. J Adv Nurs 2012;69(7):1630 - 42.

21. Gabrielle $S$, Jackson D, Mannix J. Older women nurses: health, aging concerns and self-care strategies. J Adv Nurs 2007;61(3):316 - 25.

22. Parsons K, Gaudine A, Swab M. Older nurses' experiences of providing direct care in hospital nursing units: a qualitative evidence systematic review protocol. JBI Database System Rev Implement Rep 2015;13(5):87 - 96.

23. The Joanna Briggs Institute. Joanna Briggs Institute Reviewers' Manual: 2014 edition Australia: The Joanna Briggs Institute; 2014.

24. Andrews J, Manthorpe J, Watson R. Employment transitions for older nurses: a qualitative study. J Adv Nurs 2005;51(3): 298 - 306.

25. Hodge MA. The lived experience of the older registered nurse working at the bedside in the critical care unit. [Dissertation]. Greensboro, USA: The University of North Carolina; 2009.

26. Letvak S. The experience of being an older staff nurse. West J Nurs Res 2003;25(1):45 - 56.

27. Letvak S. The experience of being an older operating room nurse. AORN J 2003;78(4):63549.

28. Letvak S. Hurting at work: the lived experience of older nurses. Intl J Human Caring 2009;13(4):8 - 16.

29. Sandy LP. Career paths of middle-aged nurses pursuing alternative career settings. [Dissertation]. Minneapolis, USA: Walden University; 2002.

30. Thompson JA. Why work in perioperative nursing? Baby boomers and generation Xers tell all. AORN J 2007;86(4): $564-87$.

31. Ultrainen K, Kyngas $\mathrm{H}$, Nikkila J. Well-being at work among ageing hospital nurses in Northern Finland: a grounded theory study. Intl J Circumpolar Health 2009;68(2):45 - 157.

32. Valencia D, Raingruber B. Registered nurses' views about work and retirement. Clin Nurs Res 2015;19(3):266-88.

33. West $S$, Boughton $M$, Byrnes $M$. Juggling multiple temporatities: the shift work story of midlife nurses. J Nurs Management 2009;17(1):110 - 9.

34. Wheeler LA. How do older nurses perceive their clinical competence and the effects of age? J Continuing Edu in Nurs 1994;25(5):230 - 6.

35. Canadian Nurses Association, [CAN]. Cited 2017 January 17]. Testing solutions for eliminating Canada's registered nursing shortage. 2013. Available from: https://www.cnaaiic.ca/ /media/cna/page-content/pdf-en/rn_highlights_e.pd-f?la=en.

36. Benner P. From novice to expert: excellence and power in clinical nursing practice. Menlo Park, (CA): Addison-Wesley; 1984.

37. Malloy DC, Fahey-McCarthy E, Masaaki MYL, Eunhee C, Eri H, Hadjistavropoulos T. Finding meaning in the work of nursing: an international study. Online J of Issues Nurs 2015;20(3):7.

38. Newton JM, Kelly CM, Kremser AK, Jolly B, Billet S. The motivation to nurse: an exploration 
of factors amongst undergraduate students, registered nurses and nurse managers. J Nurs Manage 2009;17(3):392 - 400.

39. McClure MM, Poulin M, Wandelt SM, Wandelt M. Magnet hospitals: attraction and retention of professional nurses. American Academy of Nursing Task Force on Nursing Practice in Hospitals, Kansas City, MO: American Nurses Association: 1983.

40. Kramer M, Schmalenger CE. Magnet hospital nurses describe control over nursing practice. West J Nurs Res 2003;25(4):434 - 52.

41. Scott JG, Sochalski J, Aiken L. Review of magnet hospital research: findings and implications for professional nursing practice. J Nurs Admin 1999;29(1):9 - 19.

42. Upenicks VV. Assessing differences in job satisfaction of nurses in magnet and nonmagnet hospitals. J Nurs Admin 2002;32(11):564 - 76.

43. Aiken $L$, Havens D, Sloane D. The magnet nursing services recognition program: $A$ comparison of two groups of magnet hospitals. Amer J Nurs 2000;100(3):26-35.

44. Kramer M. The magnet hospitals: excellence revisited. J Nurs Admin 1990;20(9):35 - 44.

45. Gaudine A, Thorne L. Nurses' ethical conflict with hospitals: A longitudinal study of outcomes. Nurs Ethics 2012;19(6): 727 - 37.

46. Skipper JK, Jung FD, Coffey LC. Nurses and shiftwork: Effects of physical health and mental depression. J Adv Nurs 1990;15(7):835 - 42.

47. McLauglin AM, Erdman J. Rehabilitation and staff stress as it relates to patient acuity and diagnosis. Brain Inj 1992;6(1): 59-64.

48. Hughes RG, Clancy CM. Complexity, bullying, and stress. Analyzing and mitigating a challenging work environment for nurses. J Nurs Care Qual 2009;24(3):180 - 3.

49. Jacobson BH, Aldana SG, Goetzel RZ, et al. The relationship between perceived stress and self-reported illness-related absenteeism. Am J Health Promot 1996;11(1):54 - 61.

50. Ganster DC, Shaubroeck J. Work stress and health. J of Manage 1991;17(2):235 - 71.

51. Ftouni S, Sletten TL, Barger LK, Lockley SW, Rajaratnam SMW. Chapter 29. Shift work disorder. In: Barkoukis TJ, Matheson JK, Ferber R, Doghramji K, editors. Therapy in Sleep Medicine. Philadelphia, PA: WB Saunders, 2012; 378 - 89.

52. Watson R, Manthorpe J, Andrews JA. Older nurses and employment decisions. Nurs Stand 2003;18(7):35 - 40 .

53. Canadian Nurses Association. Nurse Fatigue and Patient Safety Research Report [document on the internet]. Ottawa: Canadian Nurses Association; 2010. [cited 2017 Jan 23]. Available from https://cna-aiic.ca/ /media/cna/page-con- tent/pdfen/fatigue_safety_2010_report_e.pdf.

54. Hugh RG, Clancy CM. Complexity, bullying, and stress. Analyzing and mitigating a challenging work environment for nurses. J Nurs Care Qual 2009;24(3):180 - 3.

55. Jackson S, Schuler R. A meta-analysis and conceptual critique of research on role ambiguity and role conflict in work settings. Organ Behav and Hum Decis Process 1985;36(1): 16-78.

56. Chang YA, Huang HC, Chian CY, Hsu CP, Chang CC. Social capital and knowledge sharing: effects on patient safety. J Adv Nurs 2012;68(8):1793 - 803.

57. Klug S. Recruit, respect, and retain: The impact of Baby Boomer nurses on hospital workforce strategy - A case study. Creat Nurs 2009;5(2):70-4.

58. Spiva L, Hart P, McVay F. Discovering ways that influence the older nurse to continue bedside practice. Nurs Res Pract 2011 2011. Article ID 840120. 


\section{Appendix I: Results of the meta-synthesis of qualitative research findings}

\begin{tabular}{|c|c|c|}
\hline Findings & Categories & Synthesized findings \\
\hline Rewarding Career $(\mathrm{U})$ & \multirow[t]{18}{*}{$\begin{array}{l}\text { 1.1 Rewarding } \\
\text { work and career }\end{array}$} & \multirow{19}{*}{$\begin{array}{l}\text { 1. Love of nursing: It's who I am } \\
\text { and I love it } \\
\text { Older nurses love nursing and feel } \\
\text { as if nursing and their career as a } \\
\text { nurse is a defining factor in who } \\
\text { they are as a person. Older nurses } \\
\text { providing direct care in hospital } \\
\text { nursing units find their work and } \\
\text { their career rewarding. They have } \\
\text { been nursing long enough to feel } \\
\text { comfortable in the role and are } \\
\text { pleased by opportunities they had } \\
\text { for career advancement and } \\
\text { recognition. They know they still } \\
\text { have what it takes to be a good } \\
\text { nurse and believe that nursing is } \\
\text { about caring for others and doing } \\
\text { right by their profession. Nursing } \\
\text { also helps them to feel active and } \\
\text { fulfilled. }\end{array}$} \\
\hline $\begin{array}{l}\text { Achievement (career/self \& patient care) } \\
\text { (U) }\end{array}$ & & \\
\hline $\begin{array}{l}\text { Positive self-image - specific clinical focus } \\
\text { (U) }\end{array}$ & & \\
\hline Altruism is its own reward (U) & & \\
\hline Work itself $(U)$ & & \\
\hline Responsibility (U) & & \\
\hline Interpersonal Relations (U) & & \\
\hline Self-perception (U) & & \\
\hline Job satisfaction $(U)$ & & \\
\hline We're here because we care (U) & & \\
\hline Learning/exciting environment (U) & & \\
\hline Nurse-patient interaction (U) & & \\
\hline $\begin{array}{l}\text { Attitudes and experiences - wealth of } \\
\text { experience }(U)\end{array}$ & & \\
\hline $\begin{array}{l}\text { Attitudes and experiences - love of nursing } \\
\text { (U) }\end{array}$ & & \\
\hline $\begin{array}{l}\text { Unique contributions - sharing experiences } \\
\text { (U) }\end{array}$ & & \\
\hline $\begin{array}{l}\text { Unique contributions - making a difference } \\
\text { (U) }\end{array}$ & & \\
\hline $\begin{array}{l}\text { Working for the satisfaction of connecting } \\
\text { with patients and families }(U)\end{array}$ & & \\
\hline Growing old in the OR (U) & & \\
\hline Salary (U) & 1.2 Career & \\
\hline
\end{tabular}




\begin{tabular}{|c|c|c|}
\hline Recognition (U) & \multirow[t]{7}{*}{$\begin{array}{l}\text { advancement } \\
\text { and recognition }\end{array}$} & \\
\hline Growth (U) & & \\
\hline Status (U) & & \\
\hline Perception by others $(\mathrm{U})$ & & \\
\hline Preference of patients (U) & & \\
\hline $\begin{array}{l}\text { Wanted to be treated with respect by the } \\
\text { people she was interacting with and to } \\
\text { have responsibility for projects }(U)\end{array}$ & & \\
\hline $\begin{array}{l}\text { Hospital could not provide her the job } \\
\text { satisfaction and creative outlets she } \\
\text { required }(U)\end{array}$ & & \\
\hline \begin{tabular}{|l|} 
Professional behaviour (C) \\
Education (U)
\end{tabular} & \multirow{2}{*}{$\begin{array}{l}1.3 \text { Doing right } \\
\text { by the } \\
\text { profession. }\end{array}$} & \\
\hline Education (U) & & \\
\hline $\begin{array}{l}\text { Important needs - exercising mind and } \\
\text { body }(U)\end{array}$ & \multirow[t]{2}{*}{$\begin{array}{l}1.4 \text { Keeps me } \\
\text { active }\end{array}$} & \\
\hline Working to avoid boredom (U) & & \\
\hline Our relationship with the organization (U) & \multirow{9}{*}{$\begin{array}{l}2.1 \text { Relationship } \\
\text { with the } \\
\text { workplace }\end{array}$} & \multirow{9}{*}{$\begin{array}{l}\text { 2. It's a rewarding but challenging } \\
\text { and changing job } \\
\text { The nurses' experiences with their } \\
\text { work and workplace are both } \\
\text { positive and negative. Their life is } \\
\text { different because of shift work. } \\
\text { Although they feel valued and } \\
\text { appreciated they sometimes feel } \\
\text { discouraged, for example, with } \\
\text { their pension benefits or because } \\
\text { they feel administration would like } \\
\text { them to retire. They see } \\
\text { themselves as different from } \\
\text { younger nurses whom they believe } \\
\text { see nursing as just a job. They do } \\
\text { however, admire the assertiveness } \\
\text { of the younger nurses. They note } \\
\text { many negative aspects of nursing } \\
\text { today, including how health care } \\
\text { has become a business. They are }\end{array}$} \\
\hline Good relationships with team members (C) & & \\
\hline Nurse-nurse interaction (U) & & \\
\hline $\begin{array}{l}\text { Team support - supportive relationships } \\
\text { are important }(U)\end{array}$ & & \\
\hline $\begin{array}{l}\text { Attitudes and experiences - culture of the } \\
\text { work- place }(U)\end{array}$ & & \\
\hline Important needs - camaraderie (U) & & \\
\hline We carry our load (U) & & \\
\hline $\begin{array}{l}\text { Attitudes and experiences - appreciation of } \\
\text { learn- ing }(U)\end{array}$ & & \\
\hline $\begin{array}{l}\text { Retention factors - reduced pressure role } \\
\text { (U) }\end{array}$ & & \\
\hline
\end{tabular}




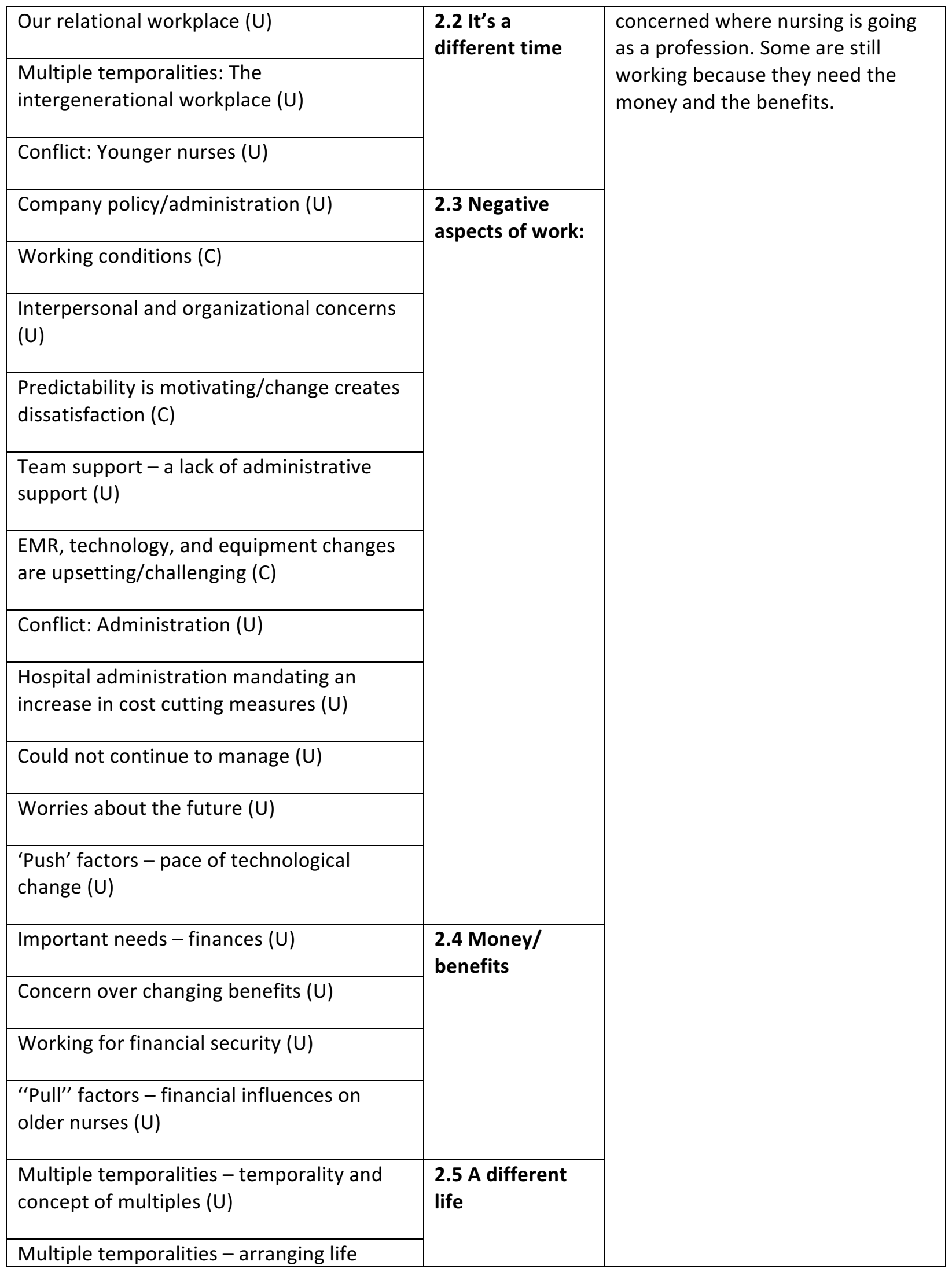




\begin{tabular}{|c|c|c|}
\hline \multicolumn{3}{|l|}{ around shift work (U) } \\
\hline Multiple temporalities - social effects (U) & & \\
\hline Energy level (U) & \multirow{12}{*}{$\begin{array}{l}\text { 3.1 Needing to } \\
\text { be physically } \\
\text { and/or mentally } \\
\text { fit }\end{array}$} & \multirow{15}{*}{$\begin{array}{l}\text { 3. It's a changing job; can I keep } \\
\text { up? } \\
\text { Older nurses voice many concerns; } \\
\text { some have memory problems, } \\
\text { some are exhausted with the ever- } \\
\text { increasing workload, some are in } \\
\text { pain, and many have concerns if } \\
\text { they can move quickly enough in } \\
\text { an emergency. Others express } \\
\text { difficulty with changes in } \\
\text { technology. Despite all this they } \\
\text { push themselves to con- tinue. } \\
\text { Older nurses describe both healthy } \\
\text { and unhealthy strategies they used } \\
\text { to help them continue working. }\end{array}$} \\
\hline Memory (U) & & \\
\hline $\begin{array}{l}\text { My practice of nursing changed - moving } \\
\text { slowly (U) }\end{array}$ & & \\
\hline $\begin{array}{l}\text { My practice of nursing changed - patient } \\
\text { safety concerns }(U)\end{array}$ & & \\
\hline Retention factors - retention strategies (U) & & \\
\hline $\begin{array}{l}\text { Retention factors - less physical challenges } \\
\text { (U) }\end{array}$ & & \\
\hline $\begin{array}{l}\text { Concern about staying healthy prompts } \\
\text { nurses to consider retirement }(U)\end{array}$ & & \\
\hline $\begin{array}{l}\text { "Push" factors - stress and older workers } \\
\text { (U) }\end{array}$ & & \\
\hline $\begin{array}{l}\text { "Pull" factors - flexible working hours for } \\
\text { older nurses (U) }\end{array}$ & & \\
\hline $\begin{array}{l}\text { Multiple temporalities - constructing a } \\
\text { personal temporality }(U)\end{array}$ & & \\
\hline Totally exhausted (U) & & \\
\hline A daily struggle - it hurts every day (U) & & \\
\hline $\begin{array}{l}\text { A daily struggle - inner strength and } \\
\text { courage }(U)\end{array}$ & \multirow[t]{2}{*}{$\begin{array}{l}\text { 3.2 Physically } \\
\text { and mentally too } \\
\text { hard }\end{array}$} & \\
\hline $\begin{array}{l}\text { Learning to cope-positive coping } \\
\text { strategies }(U)\end{array}$ & & \\
\hline $\begin{array}{l}\text { Learning to cope - negative coping } \\
\text { strategies }(U)\end{array}$ & $\begin{array}{l}\text { 3.3 Working } \\
\text { around their } \\
\text { deficits }\end{array}$ & \\
\hline
\end{tabular}


Appendix II: Search strategy

CINAHL via EBSCOhost (search conducted 13 October 2017)

\begin{tabular}{|c|c|c|}
\hline$\#$ & Query & Results \\
\hline S1 & $\begin{array}{l}\text { (MM “Nurses") OR (MM “Nursing Staff, Hospital") OR (MM "Registered } \\
\text { Nurses") OR (MM "Staff Nurses") OR (MM “Nursing Practice") OR (MM } \\
\text { "Nursing as a Profession") OR (MM “Nurse Attitudes") OR (MH "Nursing } \\
\text { Manpower") }\end{array}$ & 98,139 \\
\hline S2 & $\begin{array}{l}\text { (MM “Baby Boomers") OR (MM “Aging") OR (MM “Age Factors”) OR (MH } \\
\text { "Employment of Older Workers") }\end{array}$ & 31,391 \\
\hline S3 & S1 AND S2 & 325 \\
\hline S4 & $\begin{array}{l}\text { (MH “Nurses In Middle Age") OR (MH “Nursing Staff, Hospital In Middle } \\
\text { Age") OR (MH “Registered Nurses In Middle Age") OR (MH "Staff Nurses In } \\
\text { Middle Age") OR (MH “Nursing Practice In Middle Age") OR (MH “Nurse } \\
\text { Attitudes In Middle Age") }\end{array}$ & 170 \\
\hline S5 & $\begin{array}{l}\text { (MH “Nurses In Old Age") OR (MH "Nursing Staff, Hospital In Old Age") OR } \\
\text { (MH “Registered Nurses In Old Age") OR (MH “Staff Nurses In Old Age") OR } \\
\text { (MH “Nursing Practice In Old Age") OR (MH “Nurse Attitudes In Old Age") }\end{array}$ & 74 \\
\hline S6 & $\begin{array}{l}\text { TI (mature OR older OR aging OR ageing OR midlife OR “mid life" OR “middle } \\
\text { aged" OR "mid career" OR “late career") W1 nurse* }\end{array}$ & 291 \\
\hline S7 & $\begin{array}{l}\text { AB (mature OR older OR aging OR ageing OR midlife OR “mid life” OR } \\
\text { "middle aged" OR “mid career" OR “late career") W1 nurse* }\end{array}$ & 342 \\
\hline S8 & S3 OR S4 OR S5 OR S6 OR S7 & 974 \\
\hline S9 & $\begin{array}{l}\text { (MH “Qualitative Studies+") OR (MH “Phenomenology”) OR (MH } \\
\text { "Feminism+") OR (MH “Audiorecording”) OR (MH “Focus Groups") OR (MH } \\
\text { “Interviews+") OR (MH “Narratives") OR (MH “Observational Methods+") } \\
\text { OR (MH “Life Experiences") OR (MH “Work Experiences") OR (MH “Thematic } \\
\text { Analysis") OR (MH “Attitude+") OR TI qualitative OR AB qualitative OR TI } \\
\text { interview* OR AB interview* }\end{array}$ & 536,258 \\
\hline S10 & S8 AND S9 & 272 \\
\hline
\end{tabular}

PubMed (search conducted 13 October 2017)

\begin{tabular}{|c|c|c|}
\hline$\#$ & Query & Results \\
\hline \#1 & 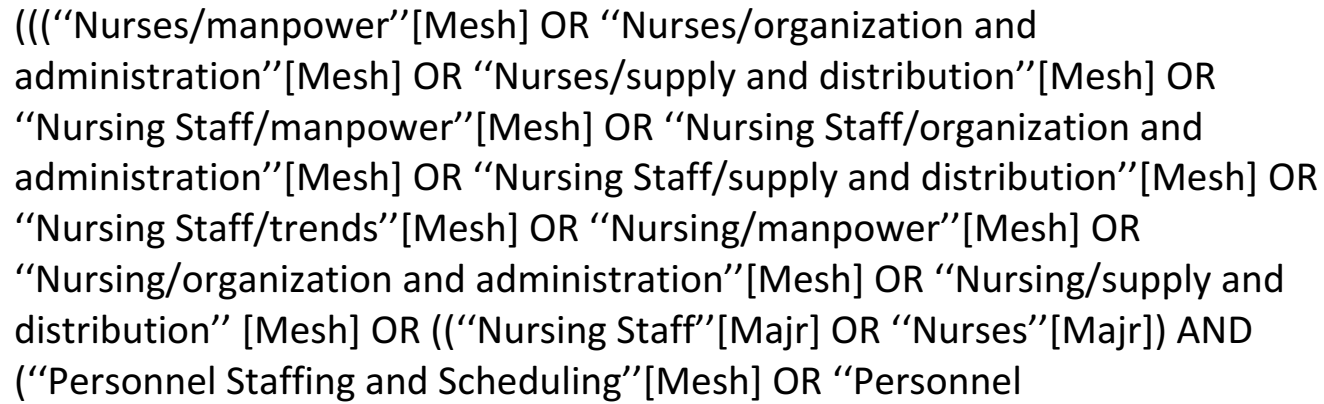 & 643 \\
\hline
\end{tabular}




\begin{tabular}{|c|c|c|}
\hline & 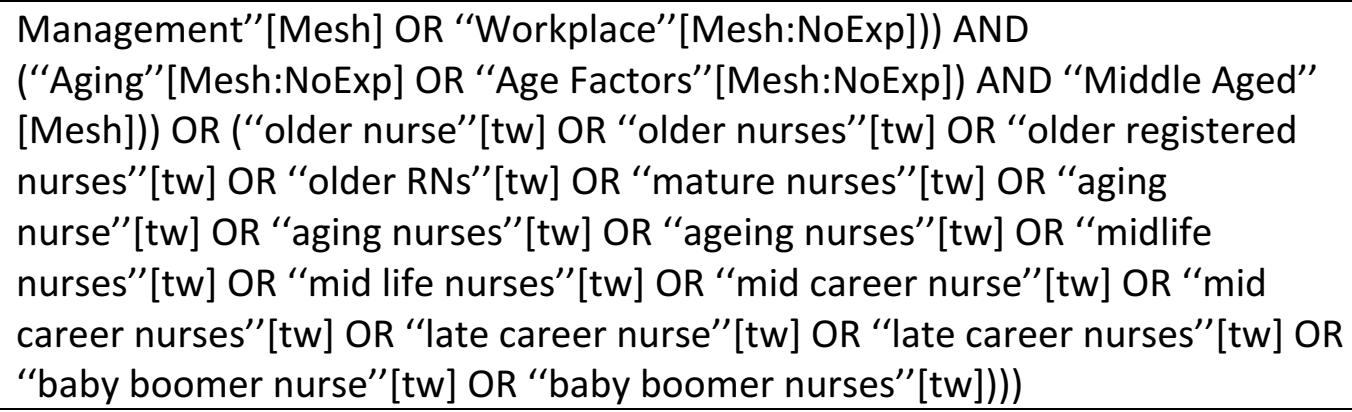 & \\
\hline$\# 2$ & 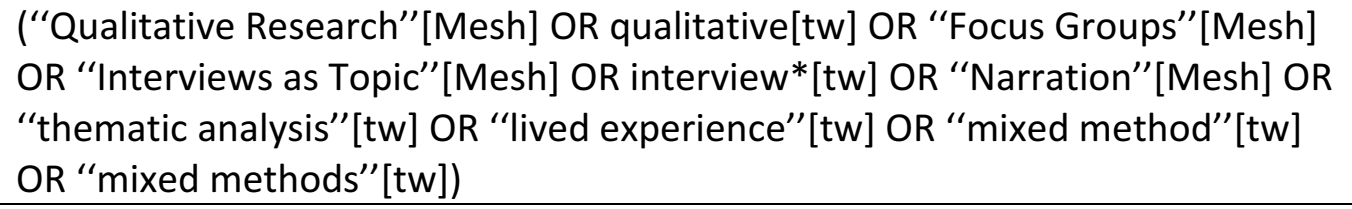 & 464,711 \\
\hline \#3 & $\# 1$ AND \#2 & 67 \\
\hline
\end{tabular}

\section{PsycINFO via EBSCOhost (search conducted 13 October 2017)}

\begin{tabular}{|c|c|c|}
\hline \# & Query & Results \\
\hline S1 & $\begin{array}{l}\text { (MM “Nurses” OR MM “Nursing") AND (DE “Aging" OR DE “Aging (Attitudes } \\
\text { Toward)" OR DE “Age Differences" OR DE “Intergenerational Relations") }\end{array}$ & 571 \\
\hline S2 & $\begin{array}{l}\text { MM “Workday Shifts" OR MM "Work (Attitudes Toward)" OR MM “Working } \\
\text { Conditions" OR MM “Job Enrichment" OR MM “Job Characteristics" OR MM } \\
\text { "Employee Retention" OR MM “Employee Turnover" OR MM "Retirement" } \\
\text { OR MM “Occupational Stress" OR MM “Diversity in the Workplace" OR MM } \\
\text { "Human Resource Management" OR MM “Management" }\end{array}$ & 65,718 \\
\hline S3 & S1 AND S2 & 51 \\
\hline S4 & $\begin{array}{l}\text { TI (mature OR older OR aging OR ageing OR midlife OR “mid life" OR “middle } \\
\text { aged" OR "mid career" OR “late career") W1 (nurse OR nurses) }\end{array}$ & 32 \\
\hline S5 & $\begin{array}{l}\text { AB (mature OR older OR aging OR ageing OR midlife OR “mid life" OR } \\
\text { "middle aged" OR “mid career" OR “late career") W1 (nurse OR nurses) }\end{array}$ & 160 \\
\hline S6 & S3 OR S4 OR S5 & 203 \\
\hline S7 & $\begin{array}{l}\text { (ZC "qualitative study") OR (ZC "focus group") OR (ZC "interview") OR DE } \\
\text { "Health Personnel Attitudes" OR TI qualitative OR AB qualitative OR TI } \\
\text { interview* OR AB interview* OR TI "mixed method" OR AB "mixed method" } \\
\text { OR TI "mixed methods" OR AB "mixed methods" }\end{array}$ & 471,910 \\
\hline S8 & S6 AND S7 & 76 \\
\hline
\end{tabular}

Embase (search conducted 13 October, 2017)

\begin{tabular}{|c|c|c|}
\hline$\#$ & Query & Results \\
\hline$\# 1$ & 'nursing staff'/mj OR 'nurse'/mj OR 'registered nurse'/mj & 81,966 \\
\hline
\end{tabular}




\begin{tabular}{|c|c|c|}
\hline$\# 2$ & $\begin{array}{l}\text { 'organization and management'/de OR 'personnel management'/de OR } \\
\text { 'health care personnel management'/exp OR 'hospital personnel } \\
\text { management'/exp OR 'manpower'/ de OR 'job satisfaction'/de OR 'work'/de } \\
\text { OR 'workplace'/de OR 'work schedule'/de OR 'employment'/de OR } \\
\text { 'occupational health'/de }\end{array}$ & 602,966 \\
\hline \#3 & 'aging'/de OR 'middle aged'/mj OR 'baby boomer'/de & 237,039 \\
\hline \#4 & \#1 AND \#2 AND \#3 & 69 \\
\hline \#5 & $\begin{array}{l}\text { ((mature OR older OR aging OR ageing OR midlife OR 'mid life' OR 'middle } \\
\text { aged' OR 'mid career' OR 'late career') NEXT/1 (nurse OR nurses)):ab,ti }\end{array}$ & 289 \\
\hline \#6 & \#4 OR \#5 & 349 \\
\hline$\# 7$ & $\begin{array}{l}\text { 'qualitative research'/exp OR qualitative:ab,ti OR 'interview'/exp OR } \\
\text { interview*:ab,ti OR 'grounded theory'/exp OR 'health personnel attitude'/de } \\
\text { OR 'nurse attitude'/exp }\end{array}$ & 642,256 \\
\hline \#8 & \#6 AND \#7 & 119 \\
\hline
\end{tabular}

AGELINE (search conducted 13 October 2017)

\begin{tabular}{|c|c|c|}
\hline$\#$ & Query & Results \\
\hline S1 & DE “Nurses" AND DE “Older Workers" & 10 \\
\hline S2 & $\begin{array}{l}\text { TI (mature OR older OR aging OR ageing OR midlife OR “mid life" OR “middle } \\
\text { aged" OR “mid career" OR “late career") W1 (nurse OR nurses) }\end{array}$ & 10 \\
\hline S3 & $\begin{array}{l}\text { AB (mature OR older OR aging OR ageing OR midlife OR “mid life" OR “middle } \\
\text { aged" OR "mid career" OR "late career") W1 (nurse OR nurses) }\end{array}$ & 64 \\
\hline S4 & S1 OR S2 OR S3 & 69 \\
\hline S5 & $\begin{array}{l}\text { DE “Qualitative Research" OR TI qualitative OR AB qualitative OR DE "Case } \\
\text { Studies" OR DE "Ethnography" OR DE "Focus Groups" OR DE "Life History } \\
\text { Research" OR DE "Participant Observation" OR DE "Research Diaries" OR DE } \\
\text { "Narratives" OR DE "Attitudes Toward Aging" OR DE "Work Attitudes" OR TI } \\
\text { interview* OR AB interview* OR TI "mixed method" OR AB "mixed method" } \\
\text { OR TI "mixed methods" OR AB "mixed methods" }\end{array}$ & 28,564 \\
\hline S6 & S4 AND S5 & 25 \\
\hline
\end{tabular}

SOCIndex (search conducted 13 October 2017)

\begin{tabular}{|l|l|r|}
\hline$\#$ & Query & Results \\
\hline S1 & $\begin{array}{l}\text { (DE “NURSES”) AND (DE “OLDER people - Employment” OR DE “OLDER } \\
\text { women - Employment” OR DE “AGE discrimination in employment”) }\end{array}$ & 1 \\
\hline
\end{tabular}




\begin{tabular}{|l|l|r|}
\hline S2 & $\begin{array}{l}\text { TI (mature OR older OR aging OR ageing OR midlife OR “mid life” OR “middle } \\
\text { aged" OR “mid career" OR “late career") W1 (nurse OR nurses) }\end{array}$ & 5 \\
\hline S3 & $\begin{array}{l}\text { AB (mature OR older OR aging OR ageing OR midlife OR “mid life" OR “middle } \\
\text { aged" OR “mid career" OR “late career") W1 (nurse OR nurses) }\end{array}$ & 23 \\
\hline S4 & S1 OR S2 OR S3 & 27 \\
\hline
\end{tabular}

Sociological Abstracts (search conducted 13 October, 2017)

\begin{tabular}{|l|l|r|}
\hline$\#$ & Query & Results \\
\hline S1 & $\begin{array}{l}\text { ti((mature OR older OR aging OR ageing OR midlife OR “mid life" OR “middle } \\
\text { aged” OR “mid career" OR “late career") N/1 (nurse OR nurses)) AND } \\
\text { ab((mature OR older OR aging OR ageing OR midlife OR “mid life” OR “middle } \\
\text { aged" OR “mid career" OR “late career") N/1 (nurse OR nurses)) }\end{array}$ & \\
\hline
\end{tabular}


Appendix III: List of study findings/conclusions/characteristics of included studies

\begin{tabular}{|c|c|c|c|c|c|}
\hline Study & Methods & Participants & $\begin{array}{l}\text { Phenomena } \\
\text { of interest }\end{array}$ & Outcomes & Notes \\
\hline $\begin{array}{l}\text { Andrews et } \\
\text { al. }^{24}\end{array}$ & $\begin{array}{l}\text { A cross- } \\
\text { sectional } \\
\text { interview } \\
\text { study using } \\
\text { face-to- face } \\
\text { or telephone } \\
\text { semi- } \\
\text { structured } \\
\text { interviews } \\
\text { with } \\
\text { thematical } \\
\text { analysis }\end{array}$ & $\begin{array}{l}84 \text { nurses } \\
\text { over } 50 \text { years } \\
\text { of age having } \\
\text { worked } \\
\text { within the } \\
\text { NHS in the } \\
\text { United } \\
\text { Kingdom and } \\
18 \text { key } \\
\text { stakeholders }\end{array}$ & $\begin{array}{l}\text { Explore the } \\
\text { influences on } \\
\text { employment } \\
\text { related } \\
\text { decision } \\
\text { making for } \\
\text { nurses and } \\
\text { key } \\
\text { stakeholders }\end{array}$ & $\begin{array}{l}\text { Local human } \\
\text { resources did } \\
\text { not reflect } \\
\text { policies and } \\
\text { strategies } \\
\text { that were } \\
\text { aimed } \\
\text { specifically at } \\
\text { older nurses. } \\
\text { The pace of } \\
\text { technological } \\
\text { change and } \\
\text { long-term } \\
\text { stress were } \\
\text { contributory } \\
\text { factors to job } \\
\text { turnover. } \\
\text { Flexibility in } \\
\text { working } \\
\text { hours was } \\
\text { important to } \\
\text { older nurses } \\
\text { in their } \\
\text { decisions to } \\
\text { remain in } \\
\text { nursing work }\end{array}$ & $\begin{array}{l}\text { No specific } \\
\text { type of } \\
\text { qualitative } \\
\text { research is } \\
\text { dis- cussed. } \\
\text { Extraction } \\
\text { was difficult } \\
\text { because the } \\
\text { illustrations } \\
\text { from the } \\
\text { nurses had to } \\
\text { be separated } \\
\text { from those of } \\
\text { the key stake- } \\
\text { holders }\end{array}$ \\
\hline $\begin{array}{l}\text { Freidrich et } \\
\text { al. }^{18}\end{array}$ & $\begin{array}{l}\text { A two phase } \\
\text { grounded } \\
\text { theory } \\
\text { approach } \\
\text { using semi- } \\
\text { structured } \\
\text { interviews }\end{array}$ & $\begin{array}{l}500 \text { bed } \\
\text { medical } \\
\text { centre in the } \\
\text { Midwestern } \\
\text { US. Phase 1, } \\
13 \text { nurses } \\
\text { over } 62 \text { years } \\
\text { actively } \\
\text { engaged in } \\
\text { acute care } \\
\text { nursing, and }\end{array}$ & $\begin{array}{l}\text { Discover } \\
\text { what rewards } \\
\text { and inspires } \\
\text { seasoned } \\
\text { nurses to } \\
\text { continue to } \\
\text { practice in } \\
\text { acute care } \\
\text { after the } \\
\text { normal age of } \\
\text { nurse }\end{array}$ & $\begin{array}{l}\text { A conceptual } \\
\text { map with } \\
\text { four themes: } \\
\text { (1) Pre- } \\
\text { existing } \\
\text { attitudes and } \\
\text { experience, } \\
\text { (2) Retention } \\
\text { factors, (3) } \\
\text { important } \\
\text { needs, and }\end{array}$ & \\
\hline
\end{tabular}




\begin{tabular}{|c|c|c|c|c|c|}
\hline & & $\begin{array}{l}\text { phase } 2,12 \\
\text { nurses 55-62 } \\
\text { years in } \\
\text { active } \\
\text { practice } \\
\text { anticipating } \\
\text { retirement }\end{array}$ & $\begin{array}{l}\text { retirement, } \\
\text { and to } \\
\text { identify best } \\
\text { practices in } \\
\text { retention }\end{array}$ & $\begin{array}{l}\text { (4) Unique } \\
\text { contribution. } \\
\text { Seasoned } \\
\text { nurses enjoy, } \\
\text { and engage in } \\
\text { nursing, and } \\
\text { derive } \\
\text { benefits from } \\
\text { continued } \\
\text { practice. } \\
\text { Many leave } \\
\text { nursing } \\
\text { because of } \\
\text { lack of } \\
\text { flexibility in } \\
\text { scheduling, } \\
\text { the additional } \\
\text { physical } \\
\text { strain and } \\
\text { musculoskele } \\
\text { tal problems. } \\
\text { Retention } \\
\text { factors } \\
\text { identified } \\
\text { included less } \\
\text { physical } \\
\text { challenges } \\
\text { and reduced- } \\
\text { pressure role }\end{array}$ & \\
\hline Hodge $^{25}$ & $\begin{array}{l}\text { Phenomenolo } \\
\text { gy. Individual } \\
\text { inter- views. } \\
\text { Colaizzi's } \\
\text { strategy for } \\
\text { analysis was } \\
\text { used. }\end{array}$ & $\begin{array}{l}11 \text { nurses ( } 8 \\
\text { females and } 3 \\
\text { males) } \\
\text { between } 52 \\
\text { and } 62 \text { years } \\
\text { of age who } \\
\text { work in a } \\
\text { critical care } \\
\text { unit of a } \\
\text { hospital in } \\
\text { Western } \\
\text { North } \\
\text { Carolina or } \\
\text { Piedmont }\end{array}$ & $\begin{array}{l}\text { Explore the } \\
\text { experiences } \\
\text { of older } \\
\text { nurses } \\
\text { involved in } \\
\text { direct patient } \\
\text { care in the } \\
\text { critical care } \\
\text { unit }\end{array}$ & $\begin{array}{l}\text { Nurses } \\
\text { discussed } \\
\text { their career } \\
\text { as being } \\
\text { rewarding } \\
\text { which } \\
\text { allowed for a } \\
\text { positive self } \\
\text { image. Their } \\
\text { nursing } \\
\text { behaviors } \\
\text { were } \\
\text { described as } \\
\text { expressions }\end{array}$ & \\
\hline
\end{tabular}




\begin{tabular}{|c|c|c|c|c|c|}
\hline & & $\begin{array}{l}\text { Region of } \\
\text { South } \\
\text { Carolina, US }\end{array}$ & & $\begin{array}{l}\text { of selfless } \\
\text { concern for } \\
\text { patients with } \\
\text { no obvious } \\
\text { reward to be } \\
\text { gained. } \\
\text { Participants } \\
\text { believed that } \\
\text { patients } \\
\text { benefited } \\
\text { from their } \\
\text { care. The } \\
\text { nurses } \\
\text { experienced } \\
\text { conflict due } \\
\text { to } \\
\text { generational } \\
\text { difference } \\
\text { and changes } \\
\text { in the } \\
\text { workplace }\end{array}$ & \\
\hline Letvak $^{26}$ & $\begin{array}{l}\text { Qualitative } \\
\text { research } \\
\text { design with } \\
\text { in-depth } \\
\text { interviews. } \\
\text { Data analysis } \\
\text { was guided } \\
\text { by the voice- } \\
\text { centered } \\
\text { relational } \\
\text { method } \\
\text { developed by } \\
\text { Brown and } \\
\text { Gilligan } \\
\text { (1992) }\end{array}$ & $\begin{array}{l}11 \text { female } \\
\text { staff nurses } \\
\text { aged } 55-62 \\
\text { years working } \\
\text { in } 6 \text { different } \\
\text { hospitals } \\
\text { located in } 4 \\
\text { counties of a } \\
\text { southeastern } \\
\text { state in the } \\
\text { US }\end{array}$ & $\begin{array}{l}\text { The } \\
\text { experience of } \\
\text { being an } \\
\text { older nurse }\end{array}$ & $\begin{array}{l}\text { Older nurses } \\
\text { were working } \\
\text { because they } \\
\text { continue to } \\
\text { care, despite } \\
\text { the stressors } \\
\text { of } \\
\text { intergenerati } \\
\text { onal conflict } \\
\text { with younger } \\
\text { nurses, less } \\
\text { respect from } \\
\text { patients and } \\
\text { families, and } \\
\text { inequity in } \\
\text { pay. Older } \\
\text { nurses are } \\
\text { confident in } \\
\text { their abilities } \\
\text { and are } \\
\text { capable of } \\
\text { meeting the }\end{array}$ & $\begin{array}{l}\text { No specific } \\
\text { type of } \\
\text { qualitative } \\
\text { research is } \\
\text { discussed. } \\
\text { However, } \\
\text { data analysis } \\
\text { is described }\end{array}$ \\
\hline
\end{tabular}




\begin{tabular}{|c|c|c|c|c|c|}
\hline & & & & $\begin{array}{l}\text { demands of } \\
\text { hospital } \\
\text { nursing }\end{array}$ & \\
\hline Letvak $^{27}$ & $\begin{array}{l}\text { Qualitative } \\
\text { research } \\
\text { design with } \\
\text { in-depth } \\
\text { interviews. A } \\
\text { feminist } \\
\text { relational } \\
\text { ontology } \\
\text { provided the } \\
\text { theoretical } \\
\text { framework } \\
\text { for the study }\end{array}$ & $\begin{array}{l}14 \\
\text { perioperative } \\
\text { nurses (13 } \\
\text { women and } 1 \\
\text { man) } \\
\text { between } 50 \\
\text { and } 62 \text { years } \\
\text { of age who } \\
\text { worked in } 5 \\
\text { hospitals } \\
\text { nursing units } \\
\text { in } 4 \text { counties } \\
\text { of a } \\
\text { southeastern } \\
\text { state }\end{array}$ & $\begin{array}{l}\text { The } \\
\text { experience of } \\
\text { being an } \\
\text { older } \\
\text { perioperative } \\
\text { nurse }\end{array}$ & $\begin{array}{l}\text { Three central } \\
\text { organizing } \\
\text { themes } \\
\text { emerged: (1) } \\
\text { Growing old } \\
\text { in the OR, (2) } \\
\text { Interpersonal } \\
\text { and } \\
\text { organizationa } \\
\text { I concerns, } \\
\text { and (3) } \\
\text { Worries } \\
\text { about the } \\
\text { future. The } \\
\text { older nurses } \\
\text { were still } \\
\text { challenged } \\
\text { and } \\
\text { energized by } \\
\text { being in the } \\
\text { OR, although } \\
\text { they had } \\
\text { concerns } \\
\text { about call } \\
\text { and } \\
\text { scheduling } \\
\text { and have } \\
\text { experienced } \\
\text { conflict with } \\
\text { surgical } \\
\text { technologists. } \\
\text { They were } \\
\text { very worried } \\
\text { about the } \\
\text { future of } \\
\text { nursing, } \\
\text { specifically } \\
\text { perioperative } \\
\text { nursing }\end{array}$ & $\begin{array}{l}\text { No specific } \\
\text { type of } \\
\text { qualitative } \\
\text { research is } \\
\text { discussed. }\end{array}$ \\
\hline
\end{tabular}




\begin{tabular}{|c|c|c|c|c|c|}
\hline Letvak $^{28}$ & $\begin{array}{l}\text { Phenomenolo } \\
\text { gy using } \\
\text { semi- } \\
\text { structured } \\
\text { interviews. } \\
\text { Data analysis } \\
\text { was guided } \\
\text { by } \\
\text { Moustakas' } \\
\text { (1994) } \\
\text { procedural } \\
\text { steps }\end{array}$ & $\begin{array}{l}13 \text { female } \\
\text { and } 1 \text { male } \\
\text { nurse ranging } \\
\text { in age for } 50 \\
\text { to } 65 \text { years } \\
\text { working in a } \\
\text { hospital } \\
\text { nursing unit }\end{array}$ & $\begin{array}{l}\text { The lived } \\
\text { experience of } \\
\text { being an } \\
\text { older nurse } \\
\text { working while } \\
\text { suffering } \\
\text { from } \\
\text { depression } \\
\text { and/ or } \\
\text { musculoskele } \\
\text { tal pain }\end{array}$ & $\begin{array}{l}\text { Four major } \\
\text { themes } \\
\text { emerged: (1) } \\
\text { A daily } \\
\text { struggle, with } \\
\text { sub- themes } \\
\text { of It hurts } \\
\text { every day and } \\
\text { Having inner } \\
\text { strength and } \\
\text { courage, (2) } \\
\text { My practice } \\
\text { of nursing } \\
\text { changed, } \\
\text { with } \\
\text { subthemes of } \\
\text { Moving } \\
\text { slowly and } \\
\text { Patient safety } \\
\text { concerns, (3) } \\
\text { Learning to } \\
\text { cope, with } \\
\text { subthemes of } \\
\text { Positive } \\
\text { coping } \\
\text { strategies } \\
\text { and Negative } \\
\text { coping } \\
\text { strategies, } \\
\text { and (4) Team } \\
\text { sup- port, } \\
\text { with } \\
\text { subthemes of } \\
\text { Supportive } \\
\text { relationships } \\
\text { are important } \\
\text { and A lack of } \\
\text { administrativ } \\
\text { e support }\end{array}$ & \\
\hline Sandy ${ }^{29}$ & $\begin{array}{l}\text { Naturalistic } \\
\text { inquiry - } \\
\text { Narrative } \\
\text { case study }\end{array}$ & $\begin{array}{l}15 \text { female } \\
\text { nurses } \\
\text { between the } \\
\text { ages of } 50\end{array}$ & $\begin{array}{l}\text { Determine } \\
\text { the } \\
\text { motivating } \\
\text { factors }\end{array}$ & $\begin{array}{l}\text { Four themes } \\
\text { emerged: (1) } \\
\text { Seeking } \\
\text { generativity, }\end{array}$ & $\begin{array}{l}\text { Extraction } \\
\text { difficult } \\
\text { because the } \\
\text { nurses were }\end{array}$ \\
\hline
\end{tabular}




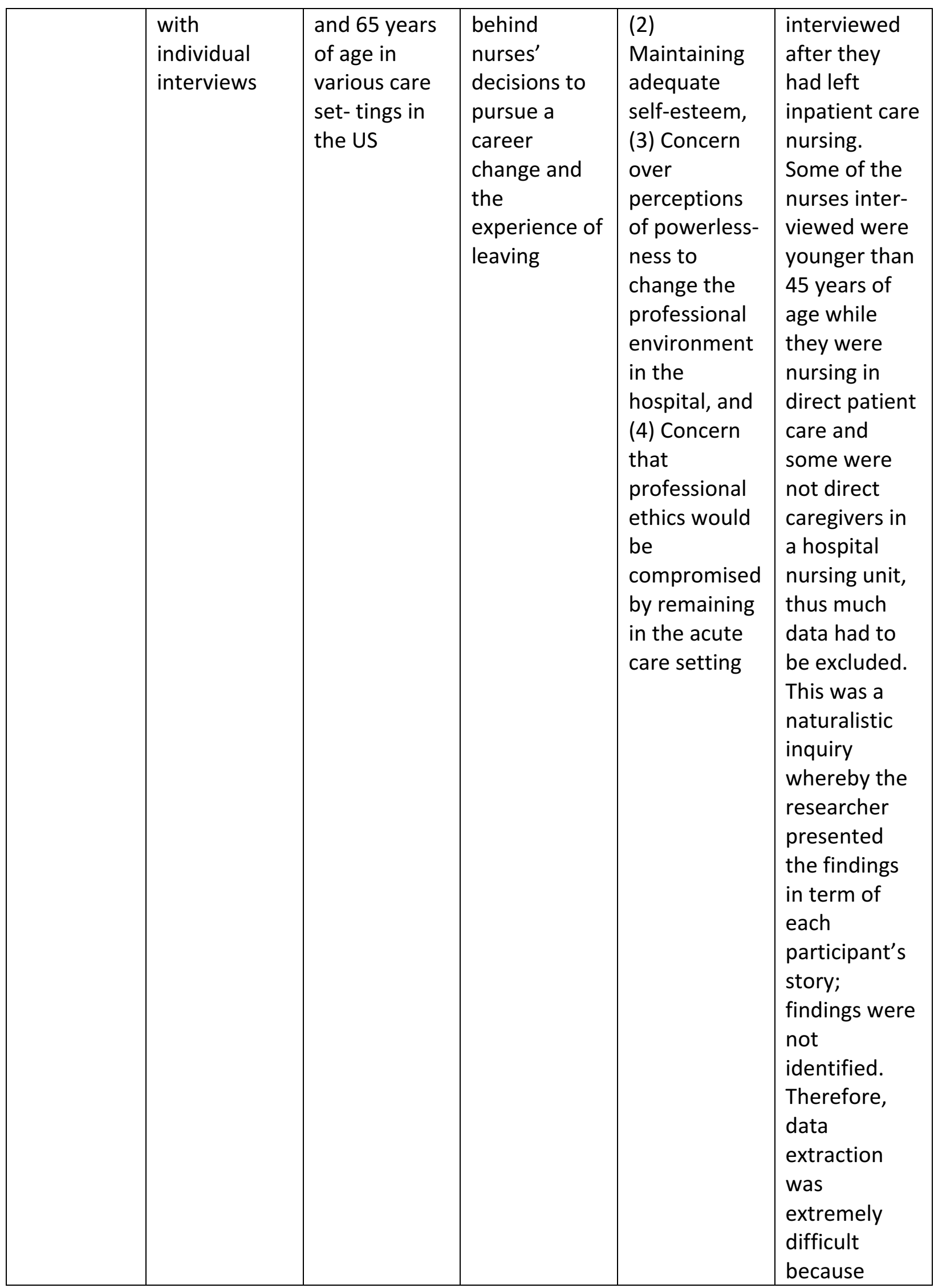




\begin{tabular}{|c|c|c|c|c|c|}
\hline & & & & & $\begin{array}{l}\text { finding had to } \\
\text { be developed } \\
\text { based on the } \\
\text { researcher's } \\
\text { closest } \\
\text { written } \\
\text { narrative. }\end{array}$ \\
\hline Thompson $^{30}$ & $\begin{array}{l}\text { Across } \\
\text { method } \\
\text { triangulation } \\
\text { (retrospective } \\
\text {, comparative } \\
\text { design and } \\
\text { phenomenolo } \\
\text { gy). Indepth } \\
\text { interviews }\end{array}$ & $\begin{array}{l}247 \text { OR staff } \\
\text { nurses } \\
\text { between } 23 \\
\text { and } 68 \text { years } \\
\text { of age in } 11 \\
\text { large, urban } \\
\text { area hospitals } \\
\text { in the } \\
\text { southwestern } \\
\text { US. The } \\
\text { qualitative } \\
\text { study } \\
\text { consisted of } \\
14 \text { nurses } \\
\text { (11 female } \\
\text { and } 3 \text { male) } \\
\text { between } 25 \\
\text { and } 58 \text { years } \\
\text { of age }\end{array}$ & $\begin{array}{l}\text { Within the } \\
\text { qualitative } \\
\text { portion of the } \\
\text { study the } \\
\text { research } \\
\text { questions } \\
\text { were: (1) } \\
\text { What factors } \\
\text { influence } \\
\text { nurses of } \\
\text { different age } \\
\text { groups to } \\
\text { choose OR } \\
\text { nursing? And, } \\
\text { (2) What } \\
\text { factors } \\
\text { influence } \\
\text { nurses of } \\
\text { different age } \\
\text { groups to } \\
\text { remain in OR } \\
\text { nursing? }\end{array}$ & $\begin{array}{l}\text { Good } \\
\text { relationships } \\
\text { with team } \\
\text { members, } \\
\text { feeling they } \\
\text { made a } \\
\text { difference to } \\
\text { patient out- } \\
\text { comes and } \\
\text { learning/ } \\
\text { excitement of } \\
\text { the } \\
\text { workplace } \\
\text { were all } \\
\text { important } \\
\text { influencing } \\
\text { nurses to } \\
\text { remain in } \\
\text { their role }\end{array}$ & $\begin{array}{l}\text { Extraction } \\
\text { was difficult } \\
\text { because data } \\
\text { from the } \\
\text { younger } \\
\text { nurses had to } \\
\text { be excluded } \\
\text { as did the } \\
\text { data that } \\
\text { addressed } \\
\text { research } \\
\text { question } 1 .\end{array}$ \\
\hline $\begin{array}{l}\text { Ultrianen et } \\
\text { al. }^{31}\end{array}$ & $\begin{array}{l}\text { Grounded } \\
\text { theory; open- } \\
\text { ended } \\
\text { questions }\end{array}$ & $\begin{array}{l}21 \text { nurses } \\
\text { between } 45 \\
\text { and } 55 \text { years } \\
\text { of age } \\
\text { working in a } \\
\text { university } \\
\text { hospital in } \\
\text { Northern } \\
\text { Finland. }\end{array}$ & $\begin{array}{l}\text { Create a } \\
\text { substantive } \\
\text { theory of the } \\
\text { well-being at } \\
\text { work among } \\
\text { ageing } \\
\text { hospital } \\
\text { nurses }\end{array}$ & $\begin{array}{l}\text { The core } \\
\text { process of } \\
\text { well-being at } \\
\text { work was } \\
\text { found to be } \\
\text { reciprocity in } \\
\text { relation to } \\
\text { colleagues } \\
\text { (nurse-nurse } \\
\text { inter- action) } \\
\text { and patients } \\
\text { (nurse- } \\
\text { patient }\end{array}$ & \\
\hline
\end{tabular}




\begin{tabular}{|c|c|c|c|c|c|}
\hline & & & & interaction) & \\
\hline $\begin{array}{l}\text { Valencia et } \\
\text { al. }^{32}\end{array}$ & $\begin{array}{l}\text { Phenomenolo } \\
\text { gy; individual } \\
\text { structured } \\
\text { interviews } \\
\text { followed by } \\
\text { thematic } \\
\text { analysis } \\
\text { according to } \\
\text { van Manen's } \\
\text { (1990) } \\
\text { approach }\end{array}$ & $\begin{array}{l}8 \text { nurses } \\
\text { between the } \\
\text { ages of } 31 \\
\text { and } 49 \text { years } \\
\text { of age and } 8 \\
\text { nurses } \\
\text { between } 50 \\
\text { and } 65 \text { years } \\
\text { of age } \\
\text { working in a } \\
\text { medical } \\
\text { intensive care } \\
\text { unit of a } \\
\text { university } \\
\text { medical } \\
\text { center in the } \\
\text { US. }\end{array}$ & $\begin{array}{l}\text { The } \\
\text { perception of } \\
\text { experienced } \\
\text { younger (31- } \\
49 \text { years) and } \\
\text { older nurses } \\
\text { (50-65 years) } \\
\text { regarding } \\
\text { continued } \\
\text { employment } \\
\text { and } \\
\text { retirement. } \\
\text { Specifically } \\
\text { the research } \\
\text { questions } \\
\text { were: (1) } \\
\text { What are the } \\
\text { things that } \\
\text { keep nurses } \\
\text { in the } \\
\text { workforce } \\
\text { longer and } \\
\text { away from } \\
\text { retirement? } \\
\text { And ( } 2 \text { ) What } \\
\text { factors } \\
\text { motivate } \\
\text { nurses to } \\
\text { retire? }\end{array}$ & $\begin{array}{l}\text { Both age } \\
\text { groups } \\
\text { shared } \\
\text { similarities in } \\
\text { things that } \\
\text { they value in } \\
\text { working. } \\
\text { Several } \\
\text { themes } \\
\text { emerged: } \\
\text { Concern over } \\
\text { changing } \\
\text { benefits; } \\
\text { working for } \\
\text { financial } \\
\text { security; } \\
\text { working to } \\
\text { provide for } \\
\text { children; } \\
\text { working for } \\
\text { the } \\
\text { satisfaction of } \\
\text { connecting } \\
\text { with patients } \\
\text { and families; } \\
\text { predictability } \\
\text { is } \\
\text { motivating/ch } \\
\text { ange creates } \\
\text { dissatisfactio } \\
\text { n; EMR, } \\
\text { technology, } \\
\text { and } \\
\text { equipment } \\
\text { changes are } \\
\text { upsetting/cha } \\
\text { llenging; } \\
\text { concern } \\
\text { about staying } \\
\text { healthy } \\
\text { prompts } \\
\text { nurses to }\end{array}$ & $\begin{array}{l}\text { Extraction } \\
\text { was difficult } \\
\text { because data } \\
\text { from the } \\
\text { younger } \\
\text { nurses had to } \\
\text { be excluded }\end{array}$ \\
\hline
\end{tabular}




\begin{tabular}{|c|c|c|c|c|c|}
\hline & & & & $\begin{array}{l}\text { consider } \\
\text { retirement; } \\
\text { working to } \\
\text { avoid } \\
\text { boredom }\end{array}$ & \\
\hline $\begin{array}{l}\text { West et } \\
\text { al. }^{33}\end{array}$ & $\begin{array}{l}\text { Phenomenolo } \\
\text { gy; Broad, } \\
\text { open- ended } \\
\text { questions; } \\
\text { followed by } \\
\text { thematic } \\
\text { analysis } \\
\text { according to } \\
\text { van Manen's } \\
\text { (1990) } \\
\text { approach }\end{array}$ & $\begin{array}{l}13 \text { nurses } \\
\text { (45- } 60 \text { years } \\
\text { of age) who } \\
\text { worked shift } \\
\text { work in a } \\
\text { hospital } \\
\text { setting in } \\
\text { urban and } \\
\text { rural } \\
\text { Australia for } \\
15 \text { years or } \\
\text { more. }\end{array}$ & $\begin{array}{l}\text { Explore the } \\
\text { shiftwork- } \\
\text { related } \\
\text { experiences } \\
\text { of mid-life } \\
\text { women }\end{array}$ & $\begin{array}{l}\text { The main } \\
\text { theme } \\
\text { identified was } \\
\text { multiple } \\
\text { temporalities. } \\
\text { Analysis } \\
\text { revealed the } \\
\text { numerous } \\
\text { temporalities } \\
\text { surrounding } \\
\text { shiftwork and } \\
\text { a sense of } \\
\text { disjunction } \\
\text { between the } \\
\text { temporalities } \\
\text { of individuals } \\
\text { important to } \\
\text { them which } \\
\text { resulted in } \\
\text { feelings of } \\
\text { regret and } \\
\text { guilt. The } \\
\text { concept of } \\
\text { juggling is } \\
\text { introduced to } \\
\text { illustrate the } \\
\text { participants' }\end{array}$ & \\
\hline Wheeler $^{34}$ & $\begin{array}{l}\text { Qualitative; } \\
\text { descriptive } \\
\text { study. } \\
\text { Individual } \\
\text { face- to-face } \\
\text { interviews }\end{array}$ & $\begin{array}{l}8 \text { female staff } \\
\text { nurses }(50- \\
62 \text { years of } \\
\text { age) }\end{array}$ & $\begin{array}{l}\text { Determine } \\
\text { the } \\
\text { perceptions, } \\
\text { attitudes and } \\
\text { beliefs about } \\
\text { their } \\
\text { professional } \\
\text { competence } \\
\text { and how they } \\
\text { believed they }\end{array}$ & $\begin{array}{l}\text { Nurses felt } \\
\text { good about } \\
\text { themselves } \\
\text { and the } \\
\text { profession, } \\
\text { and valued } \\
\text { traditional } \\
\text { bedside } \\
\text { nursing and } \\
\text { professional }\end{array}$ & $\begin{array}{l}\text { No specific } \\
\text { type of } \\
\text { qualitative } \\
\text { research is } \\
\text { discussed. }\end{array}$ \\
\hline
\end{tabular}




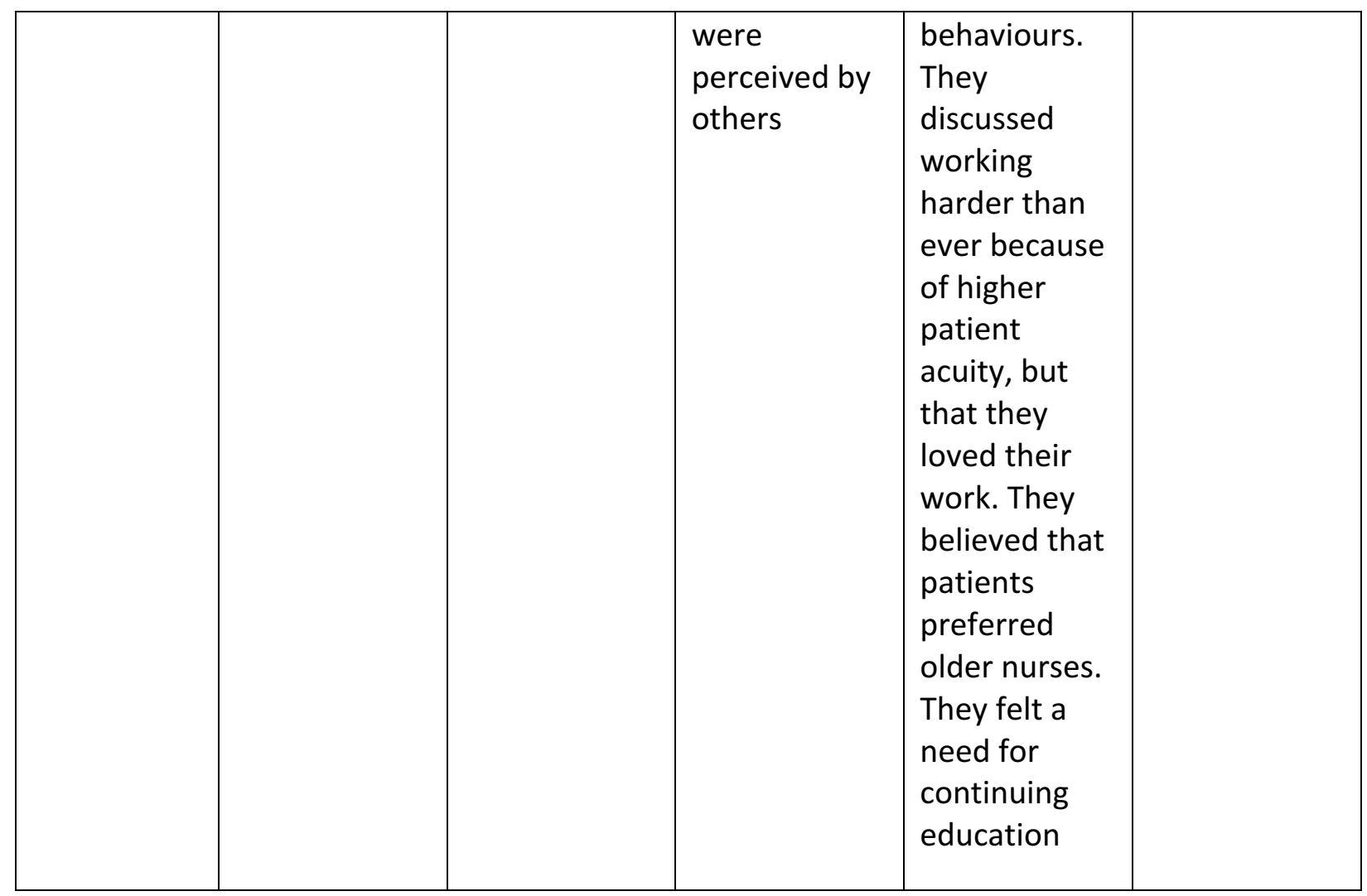




\section{Appendix IV: Excluded studies}

Klug S. Recruit, respect, and retain: The impact of Baby Boomer nurses on hospital workforce strategy - A case study. Creat Nurs 2009;5(2):70-4.57

Reason for exclusion: Findings are not identified and insufficient illustrations

Spiva L. Hart P and McVay F. Discovering ways that influence the older nurse to continue bedside practice. Nurs Res Pract 2011 (2011), Article ID 84012058

Reason for exclusion: Incongruity between philosophical perspective, research methodology, analysis and interpretation of results 